\title{
27. MICROFABRIC AND MICROCOMPOSITIONAL STUDIES OF PLIOCENE AND QUATERNARY SAPROPELS FROM THE EASTERN MEDITERRANEAN ${ }^{1}$
}

\author{
Alan E.S. Kemp, ${ }^{2}$ Richard B. Pearce, ${ }^{2}$ Jennifer Pike, ${ }^{2}$ and John E.A. Marshall ${ }^{3}$
}

\begin{abstract}
An electron-microscope analysis of the microfabrics and microcomposition of Mediterranean sapropels revealed distinctive types of lamina components and significant variation in preservation of laminae. Individual laminae are composed predominantly of (1) terrigenous silty clay, (2) organic (carbon) material, and (3) diatoms. Opal is rarely present, and where preserved, diatom floras show evidence for variable silica dissolution. It is suggested that most sapropels originally included abundant diatoms, but that these subsequently dissolved, and that the most commonly preserved lamina style of alternating organic and terrigenous laminae represents a "remnant" fabric. The diatom floras within the sapropels are consistent with palynofacies data that provide evidence for increased fluvial input, which leads to enhanced stratification. The preservation of fabrics within sapropels indicates increasing dominance of bottom-water anoxia during the sedimentation of individual sapropels. The bioturbation of the upper part of some sapropel horizons may reflect conditions after cessation of sapropel deposition. The evidence from microfabric studies thus supports models of sapropel formation involving increased nutrient input and water column stratification.
\end{abstract}

\section{INTRODUCTION}

The origin of the Mediterranean sapropels has been the subject of intense debate by the geological and oceanographic communities. Most recently, this debate has been fueled by the broader question concerning the relative importance of high organic productivity and flux vs. water column stratification and anoxia in the production of organic-rich sediments, such as sapropels or black shales (Pederson and Calvert, 1990). Many multidisciplinary studies using conventional paleoceanographic indicators have been undertaken on sapropels, yet there have been no studies of the fine structure of these sediments, several of which are laminated. This paper reports the preliminary results of scanning electron microscope (SEM)-based studies of the fine structure of sapropels recovered from Ocean Drilling Program Leg 160 in the Eastern Mediterranean (Fig. 1).

Back-scattered electron imagery (BSEI) has been used by various workers to provide information on mudrocks and, in particular, black shales (Macquaker and Gawthorpe, 1993). More recently, BSEI has been applied to unconsolidated sediments that have been impregnated, either by vacuum impregnation or by displacive fluid impregnation (see Pike and Kemp, 1996, for a summary of techniques used). In some studies, researchers have also undertaken compositional Xray microanalysis of both recent sediments and ancient shales (Bishop et al., 1992). The purpose of this paper is to provide an overview of the range of compositional microfabrics present in Eastern Mediterranean sapropels based on combined use of BSEI and compositional mapping by use of energy dispersive X-ray microanalysis. To complement the SEM-led approach, standard diatom micropaleontological analysis and organic palynofacies analysis techniques were employed in parallel to characterize the diatom floras and palynology of the sediments.

${ }^{1}$ Robertson, A.H.F., Emeis, K.-C., Richter, C., and Camerlenghi, A. (Eds.), 1998. Proc. ODP, Sci. Results, 160: College Station, TX (Ocean Drilling Program).

${ }^{2}$ Department of Oceanography, University of Southampton, Southampton Oceanography Centre, European Way, Southampton, SO14 3ZH, United Kingdom. aesk@mail.soc.soton.ac.uk

${ }^{3}$ Department of Geology, University of Southampton, Southampton Oceanography Centre, European Way, Southampton, SO14 3ZH, United Kingdom.

\section{METHODS}

\section{SEM Techniques}

Sediment samples were prepared for SEM study by impregnation using epoxy resin. This was undertaken either by vacuum impregnation in a Logitech vacuum impregnation apparatus or by displacive fluid impregnation using a method slightly modified from that described in Pike and Kemp (1996). The modifications used helped to facilitate the impregnation of sediments rich in clay-sized material. In outline, the resin is prepared using several chemicals in the following ratio:

$$
\begin{array}{lr}
\text { vinylcyclohexene dioxide (VCD) } & 10.0 \mathrm{~g} \\
\text { diglycidol ether of polypropyleneglycol } & \\
\quad \text { (DER 736) } & 6.0 \mathrm{~g} \\
\text { nonenyl succinic anhydride (NSA) } & 26.6 \mathrm{~g} \\
\text { dimethylaminoethanol (DMAE) } & 0.2 \mathrm{~g}
\end{array}
$$

Samples of wet sediment are placed in close-fitting, well-perforated, aluminum foil containers and immersed in high-purity acetone within a glass desiccator containing silica gel. Acetone is replaced three times daily for five days. This chemically dries the sediment by replacing the aqueous pore fluids with the solvent. Samples must not be allowed to desiccate at any stage. After the final soaking with acetone, this is removed and an acetone/resin mixture added, in which the resin content is increased by stages: (1) the first three additions of the acetone/resin mixture were in the proportion 50:50, (2) the second three in the proportion $25: 75$, (3) the third three in the proportion 10:90, and (4) the remaining six consisted of resin only. These acetone/resin and resin replacements are undertaken every $12 \mathrm{hr}$ (to prevent viscosity increase).

Samples are left to soak for up to four weeks (in the desiccator) after the last addition of resin, ensuring that all of the pore spaces are filled. Samples are then cured for $72 \mathrm{hr}$ at $30^{\circ} \mathrm{C}$, and $24 \mathrm{hr}$ at both $45^{\circ} \mathrm{C}$ and $60^{\circ} \mathrm{C}$, allowing the resin to cool between each stage. Preparation of thin sections from the resin blocks is undertaken using an oil-based rather than a water-based lubricant. For the initial laminascale studies, priority was given to the intact part of the horizon. 


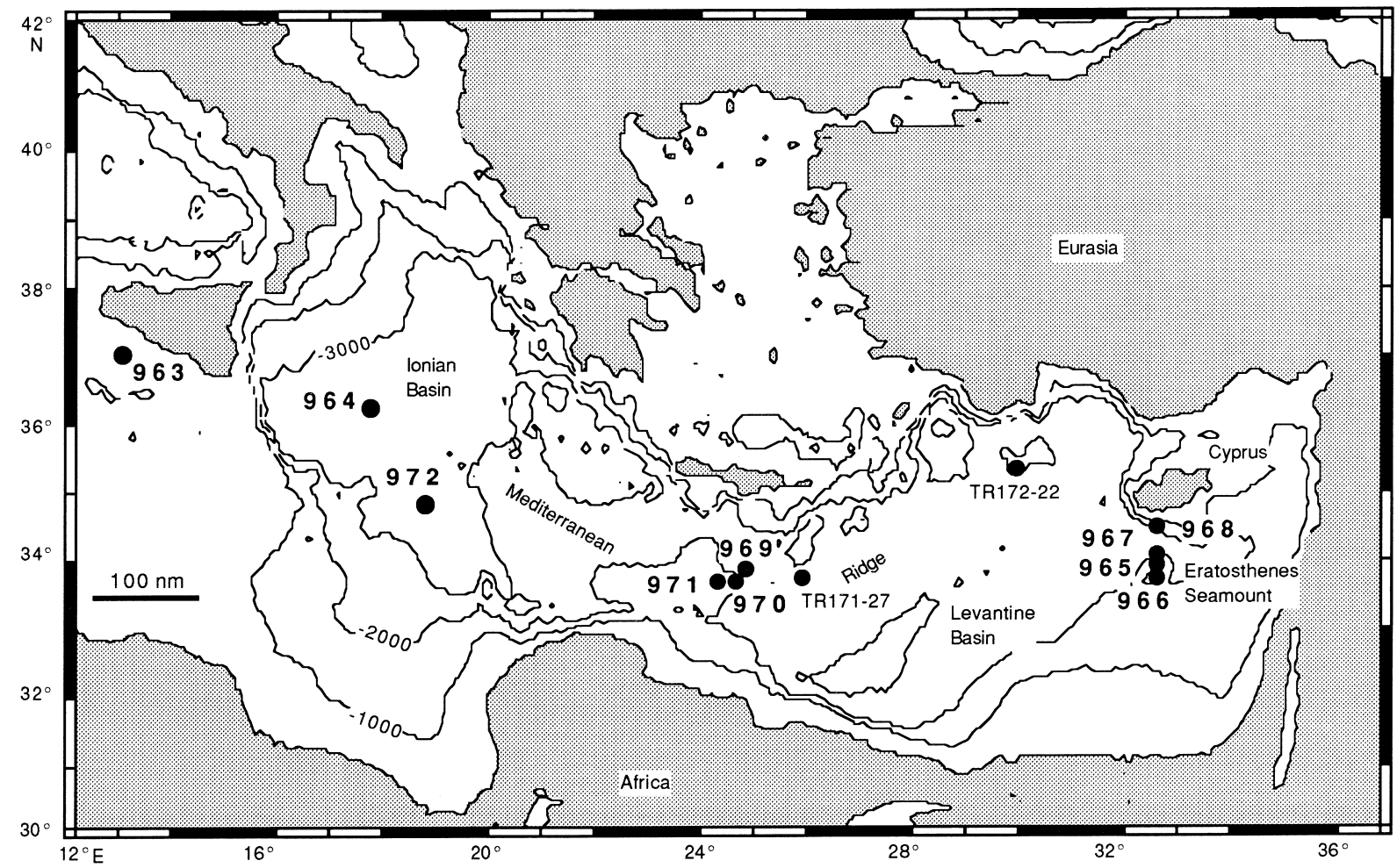

Figure 1. Map of the Mediterranean showing the locations of ODP Leg 160 coring sites together with piston core Sites TR171-27 and TR172-22 that contain S5 diatoms from Schrader and Matherne (1981). Piston Cores TR171-27 and TR172-22 were collected during R/V Trident Cruises 171 and 172. Contours are in meters below sea level.

Low-resolution BSEI was used to provide base maps for more detailed imagery of lamina composition. Subsamples of sediment were prepared for topographic secondary electron imagery and BSEI to provide analysis of microfossil components. Identification of changes in diatom-species composition from the BSEI study was used as a basis for separation of lamina-scale samples for ultra-high resolution micropaleontological analyses and biomarker studies. Energy dispersive $\mathrm{X}$-ray microanalysis was undertaken using individual spot analysis, line scans, and elemental maps of $\mathrm{C}, \mathrm{O}, \mathrm{Cl}, \mathrm{Ca}, \mathrm{Na}, \mathrm{Mg}, \mathrm{Al}, \mathrm{Si}, \mathrm{P}$, $\mathrm{S}, \mathrm{K}$, and $\mathrm{Fe}$.

\section{Quantitative Diatom Micropaleontological Analysis}

Preparation of the sediment for quantitative diatom slides followed the method of Lange and Berger (1993), but the settling technique used to evenly distribute material over cover slips was adapted from Bodén (1991). Briefly, each sample was freeze dried, and its dry weight determined. Dry samples were placed in $400 \mathrm{~mL}$ beakers and boiled in a solution of sodium pyrophosphate and hydrogen peroxide (30\%), followed by treatment with hydrochloric acid. The samples were then cleaned with deionized water and allowed to settle for $8 \mathrm{hr}$. The supernatant was decanted off, and the dilution procedure repeated. This dilution/decanting cycle was completed four times, and then samples were diluted to a known volume. Cover slips of acid-cleaned material were prepared using a settling technique and mounted onto slides using Naphrax mounting medium. Diatoms were counted at $\times 1000$ magnification using the counting convention of Schrader and Gersonde (1978), as modified by Laws (1983), and diatom valve concentration (DVC) per gram dry sediment was calculated as:

$$
\mathrm{DVC}=\frac{\mathrm{WD} \times \mathrm{AC} \times \mathrm{ND}}{\mathrm{WS} \times \mathrm{AV} \times \mathrm{NV} \times \mathrm{VS}},
$$

where WD = weight of sample solution, $\mathrm{AC}=$ area of settling container, $\mathrm{ND}=$ number of diatoms counted, $\mathrm{WS}=$ weight of dry initial sample, $\mathrm{AV}=$ area of microscope view-field, $\mathrm{NV}=$ number of viewfields, and VS = volume of subsample used settling onto cover slips (Bodén, 1991).

\section{Palynofacies Analysis}

Samples, $1 \mathrm{~g}$ in weight, were demineralized in HCI\HF using standard procedures followed by decantation to neutral and sieving at 20 $\mu \mathrm{m}$. The resulting kerogen isolates were then subjected to a brief treatment in hot, concentrated $\mathrm{HCl}$ to remove neoformed fluorides. A Lycopodium spike in tablet form (Stockmarr, 1971) was added. Microscopical examination of the samples showed them to be very rich in amorphous organic matter (AOM). To facilitate study of the structured organic matter, this AOM was largely removed with a $10-\mathrm{s}$ treatment from a $600 \mathrm{~W}$ Jencons high-intensity ultrasonic probe followed by sieving. The resulting kerogen residues were then mounted in Elvacite 2044, and the structured components counted as particles (as opposed to area covered by different size particles) against the $L y$ copodium spike. This provides an assessment of the "absolute" abundance of each structured kerogen component independent of any other component. This is particularly significant to avoid closed-sum problems inherent in percentage data.

\section{RESULTS OF MICROFABRIC ANALYSIS}

A broad range of microfabrics are encountered in the sapropels examined from laminated through intermittently laminated, to those exhibiting micro-scale bioturbation through to macro-scale bioturbation. A summary of the results of microfabric analysis is given for 
each sapropel analyzed in Table 1 . The occurrence of diatoms in analyzed sapropels is given in Table 2. Illustrations of examples of the microfabrics described are given in Figures 2-5 and Plates 1-5.

\section{Occurrence of Gray Laminae and Thin Beds Within Sapropels}

Some sapropels contain laminae or thin beds of gray or greenish gray mud. There has been some debate about whether such layers represent turbiditic interbeds within sapropels, or whether they represent an interruption of the conditions of sapropel deposition. In one such instance BSEI was used and showed that the thin mud interbed possessed a thin, graded interval of very fine sand and silt at its base (Pl. 1).

\section{Laminated Sapropels}

Comprehensive BSEI investigations of 71 polished thin sections from 15 Pleistocene and Pliocene sapropels revealed a range of lamina styles and compositions. Among relatively well-laminated sapropels, three common types of lamina composition were recognized: (1) clay/silt laminae; (2) organic-rich laminae; and (3) diatomrich laminae. Lamination was generally defined by an alternation of two or more of these components. An exceptional sapropel composed mainly of diatom ooze with minor mineralogenic material was the S5 at Holes 971B and 971C. This bed, which is discussed in detail elsewhere (Pearce et al., Chap. 28, this volume), is unique in that successive laminae are distinguished by different diatom species composition. Although some other sapropels contain diatoms (Table 2), they show evidence for dissolution of opal (compare Pl. 2, Figs. 1, 2).

Table 1. Summary of the samples analyzed in the microfabric studies.

\begin{tabular}{|c|c|c|c|c|c|}
\hline Sapropel & Hole, core, section, interval $(\mathrm{cm})$ & $\begin{array}{l}\text { Depth } \\
\text { (mbsf) }\end{array}$ & $\begin{array}{c}\text { PTS } \\
\text { preparation } \\
\text { technique }\end{array}$ & $\begin{array}{c}\text { Number } \\
\text { of PTS } \\
\text { prepared }\end{array}$ & Summary of microcomposition \\
\hline S5 & $967 \mathrm{~B}-2 \mathrm{H}-1,107-136$ & 6.40 & V-I & 8 & Massive \\
\hline S5 & $971 \mathrm{~A}-1 \mathrm{H}-3,37-66$ & 3.42 & F-D & 7 & Massive \\
\hline S5 & $971 \mathrm{C}-2 \mathrm{H}$ through $3 \mathrm{H}$ & 8.70 & V-I/F-D & 35 & Laminated diatom ooze \\
\hline S6 & 967D-2H-1, 130 through 967D-2H-2, 42 & 8.00 & V-I & 13 & Massive \\
\hline S8 & $967 \mathrm{D}-2 \mathrm{H}-3,60-110$ & 10.30 & V-I/F-D & 3 & Massive \\
\hline 42 & 964E-4H-2, 130 through 964E-4H-3, 15 & 60.10 & V-I & 3 & Massive \\
\hline 47 ("e" bed) & $967 \mathrm{C}-6 \mathrm{H}-2,30-46$ & 49.30 & F-D & 5 & Laminated packets, streaky fabric \\
\hline 47 ("e" bed) & $969 \mathrm{D}-5 \mathrm{H}-2,42-76$ & 39.32 & F-D & 12 & Laminated packets, streaky fabric \\
\hline 55 & $964 \mathrm{E}-6 \mathrm{H}-4,108-124$ & 81.64 & F-D & 3 & Laminated and reworked horizons \\
\hline 62 (“A”group) & $969 \mathrm{~A}-6 \mathrm{H}-1,127-142$ & 46.98 & F-D & 5 & Massive \\
\hline 71 (“O”' group) & 969B-7H-1, 14-28 & 50.55 & F-D & 5 & Laminated packets, streaky fabric \\
\hline 71 (“O” group) & 969E-6H-6, 23-41 & 50.67 & F-D & 5 & Laminated packets, streaky fabric \\
\hline Basal sapropel & $969 \mathrm{~B}-11 \mathrm{H}-6,121-128$ & 97.11 & F-D & 2 & Foraminifer laminae \\
\hline
\end{tabular}

Note: $\mathrm{PTS}=$ polished thin section; V-I = vacuum impregnation; F-D = fluid displacive impregnation

Table 2. The occurrence of diatoms in sapropels analyzed.

\begin{tabular}{|c|c|c|c|c|}
\hline $\begin{array}{c}\text { Evidence for diatoms or } \\
\text { other siliceous } \\
\text { microorganisms }\end{array}$ & $\begin{array}{l}\text { State of opal } \\
\text { preservation }\end{array}$ & Sapropel & $\begin{array}{l}\text { Hole, core, section, } \\
\text { interval }(\mathrm{cm})\end{array}$ & $\begin{array}{l}\text { Depth } \\
\text { (mbsf) }\end{array}$ \\
\hline \multirow[t]{3}{*}{ YES } & Poor & S5 & 967B-2H-1, 107-136 & 6.40 \\
\hline & Excellent & S5 & $971 \mathrm{C}-2 \mathrm{H}$ through $3 \mathrm{H}$ & 8.70 \\
\hline & Poor & 47 or "e" bed & $969 \mathrm{D}-5 \mathrm{H}-2,42-76$ & 39.32 \\
\hline \multirow[t]{29}{*}{ NO } & & S5 & 964B-1H-5, 116-138 & 7.38 \\
\hline & & S5 & $971 \mathrm{~A}-1 \mathrm{H}-3,37-66$ & 3.42 \\
\hline & & S6 & $\begin{array}{l}967 \mathrm{D}-2 \mathrm{H}-1,130-150 \\
\text { through } 967 \mathrm{D}-2 \mathrm{H}-2,0-42\end{array}$ & 8.00 \\
\hline & & S7 & $967 \mathrm{D}-2 \mathrm{H}-2,130-150$ & 9.70 \\
\hline & & S8 & $964 \mathrm{E}-2 \mathrm{H}-1,97-133$ & 6.56 \\
\hline & & S8 & $967 \mathrm{D}-2 \mathrm{H}-3,60-110$ & 10.30 \\
\hline & & 9 & $964 \mathrm{E}-3 \mathrm{H}-2,90-110$ & 17.21 \\
\hline & & 10 & $964 \mathrm{E}-3 \mathrm{H}-3,63-88$ & 18.70 \\
\hline & & 11 & $964 \mathrm{E}-3 \mathrm{H}-4,44-58$ & 20.00 \\
\hline & & 12 & $964 \mathrm{E}-3 \mathrm{H}-4,78-101$ & 20.40 \\
\hline & & 41 & $964 \mathrm{E}-4 \mathrm{H}-2,14-48$ & 58.86 \\
\hline & & 42 & $\begin{array}{l}964 \mathrm{E}-4 \mathrm{H}-2,130-150 \\
\quad \text { through } 964 \mathrm{E}-4 \mathrm{H}-3,0-15\end{array}$ & 60.10 \\
\hline & & 26 & $966 \mathrm{C}-5 \mathrm{H}-4,0-15$ & 42.63 \\
\hline & & 47 or "e" bed & $967 \mathrm{C}-6 \mathrm{H}-2,30-46$ & 49.30 \\
\hline & & 48 & $964 \mathrm{E}-5 \mathrm{H}-5,82-104$ & 73.42 \\
\hline & & 49 & $967 \mathrm{C}-6 \mathrm{H}-2,142-150$ & 50.31 \\
\hline & & 55 & $964 \mathrm{E}-6 \mathrm{H}-4,108-124$ & 81.64 \\
\hline & & 57,58 & $964 \mathrm{E}-6 \mathrm{H}-5,72-112$ & 82.88 \\
\hline & & 62 & 967C-7H-6, 93-112 & 65.43 \\
\hline & & 62 & $969 \mathrm{~A}-6 \mathrm{H}-1,127-142$ & 46.98 \\
\hline & & 71 & 969 A-6H-6, 147-150 & 54.33 \\
\hline & & 71 & $969 \mathrm{~B}-7 \mathrm{H}-1,14-28$ & 50.55 \\
\hline & & 71 & $969 \mathrm{E}-6 \mathrm{H}-6,23-41$ & 50.67 \\
\hline & & 77 & $967 \mathrm{C}-8 \mathrm{H}-6,41-57$ & 74.43 \\
\hline & & 78 & $967 \mathrm{C}-8 \mathrm{H}-6,82-95$ & 74.82 \\
\hline & & Basal sapropel & $969 \mathrm{~B}-11 \mathrm{H}-6,57-90$ & 96.47 \\
\hline & & Basal sapropel & $969 \mathrm{~B}-11 \mathrm{H}-6,121-128$ & 97.11 \\
\hline & & $*$ & $963 \mathrm{~B}-23 \mathrm{H}-2,34-53$ & 191.74 \\
\hline & & $*$ & $963 \mathrm{~B}-24 \mathrm{H}-2,71-93$ & 199.71 \\
\hline
\end{tabular}

Note: $*=$ laminated sediment (not sapropelic). 


\section{The " $e$ " Bed at Site 967}

This sapropel horizon was correlated with the early Pleistocene "e" horizon of the Vrica section (C6 of the Singa section) of Calabria, Southern Italy (Hilgen, 1991). Shipboard organic-carbon analysis gave a value of 7 weight percent (wt \%) total organic carbon (TOC). The sapropel has a sharp lower boundary, and the main bed is 11.5 $\mathrm{cm}$ thick with two thin $(\sim 5 \mathrm{~mm})$ upper beds that are heavily burrowed. The upper beds are separated by ungraded nannofossil silty clay. A summary of the fabrics encountered is given in Figure 2. Most of the "e" bed at Site 967 contains a streaky, discontinuous lamination defined by relatively thin $(5-75 \mu \mathrm{m})$ streaks or laminae of organic matter that are laterally impersistent and show evidence for minor disruption, including $100-\mu \mathrm{m}$ to millimeter-scale burrows. In a few intervals towards the top of the bed, more intact, continuous lamination is present in which laterally persistent organic and terrigenous laminae alternate with thinner anastomosing organic sublaminae ( $\mathrm{Pl}$. 3 ). Coccoliths, and occasionally compacted coccospheres, are a component of both the silty clay and organic carbon-rich laminae but are more often concentrated in the latter. Pyrite is often concentrated within the thicker organic laminae (Pl. 3, Fig. 1). Within the silty clay laminae, local concentrations of clay-grade material occur (Pl. 3, Fig. 2).

\section{The "e" Bed at Site 969}

The equivalent sapropel to the "e" horizon of the Vrica section was also sampled at Site 969 . Here the main sapropel bed is $25 \mathrm{~cm}$ thick (more than double that at Site 967), but the distinctive two thin, upper sapropel horizons are also present (Fig. 3). Shipboard organiccarbon analysis gave values of 10-16 wt $\%$ TOC. The lamina fabric contrasts strongly with that of the Site 967 "e" horizon, because diatoms are a major component of the Site 969 "e" bed. The laminae comprise an alternation of relatively thin $(10-30 \mu \mathrm{m})$ variably continuous $(<100 \mu \mathrm{m}$ to $\sim 1 \mathrm{~mm}$ ) laminae or streaks of silty clay, with thicker $(25-75 \mu \mathrm{m})$ diatom-rich laminae with coccoliths and minor silt and clay (Pl. 4). Streaks or lenses of organic material, including plant and wood fragments $(5-30 \mu \mathrm{m})$, also occur, sometimes as discrete sublaminae within diatomaceous laminae, but also in contact with terrigenous silty clay (Pl. 4, Figs. 2, 4, 5). Within this sapropel, thin intervals of more intact and laterally persistent laminae alternate with zones of discontinuous, lensoid or pellet-like structures (Pl. 4, Fig. 1). Zones of more persistent laminae are more common in the upper part of the main bed, although (as with the Site 967 "e" horizon) the topmost $5 \mathrm{~mm}$ and the two, thin overlying horizons are affected by Chondrites burrows.

\section{Pliocene “0” Group Sapropel at Site 969}

A sapropel horizon from the Pliocene "0" group (Hilgen, 1991) was sectioned and examined both in Holes 969E and 969B. A summary of the variation in fabrics is given in Figure 4. Shipboard organic-carbon analysis gave values of $28.5 \mathrm{wt} \%$ TOC. The lamination is defined by alternations of thin $(5-25 \mu \mathrm{m})$ streaks and discontinuous $(<200 \mu \mathrm{m})$ sublaminae of clay or silty clay with organic carbon-rich laminae with pyrite, between 10 and $25 \mu \mathrm{m}$ thick and exceptionally up to $50 \mu \mathrm{m}$ thick (Pl. 2, Figs. 2, 3). Although the lower part of this horizon is pervasively deformed by faulting (in both holes examined), the overall pattern of fabric is one of increasingly continuous lamination observed in the mid-upper part of the bed, but with Chondrites burrowing from the top.

\section{Pliocene “0” Group Sapropel at Site 964}

This horizon comprises a thin, double sapropel, with a lower 1$\mathrm{cm}$-thick bed, an intervening 7-mm-thick nannofossil clay, and a 2.5$\mathrm{cm}$ upper bed (Fig. 5). The lower bed is completely bioturbated and homogenized. The upper bed contains a lower zone of millimeter-
Core Interval: $160-967 \mathrm{C}-6 \mathrm{H}-2,30-46 \mathrm{~cm}$ Core Interval, Lithology Fabric

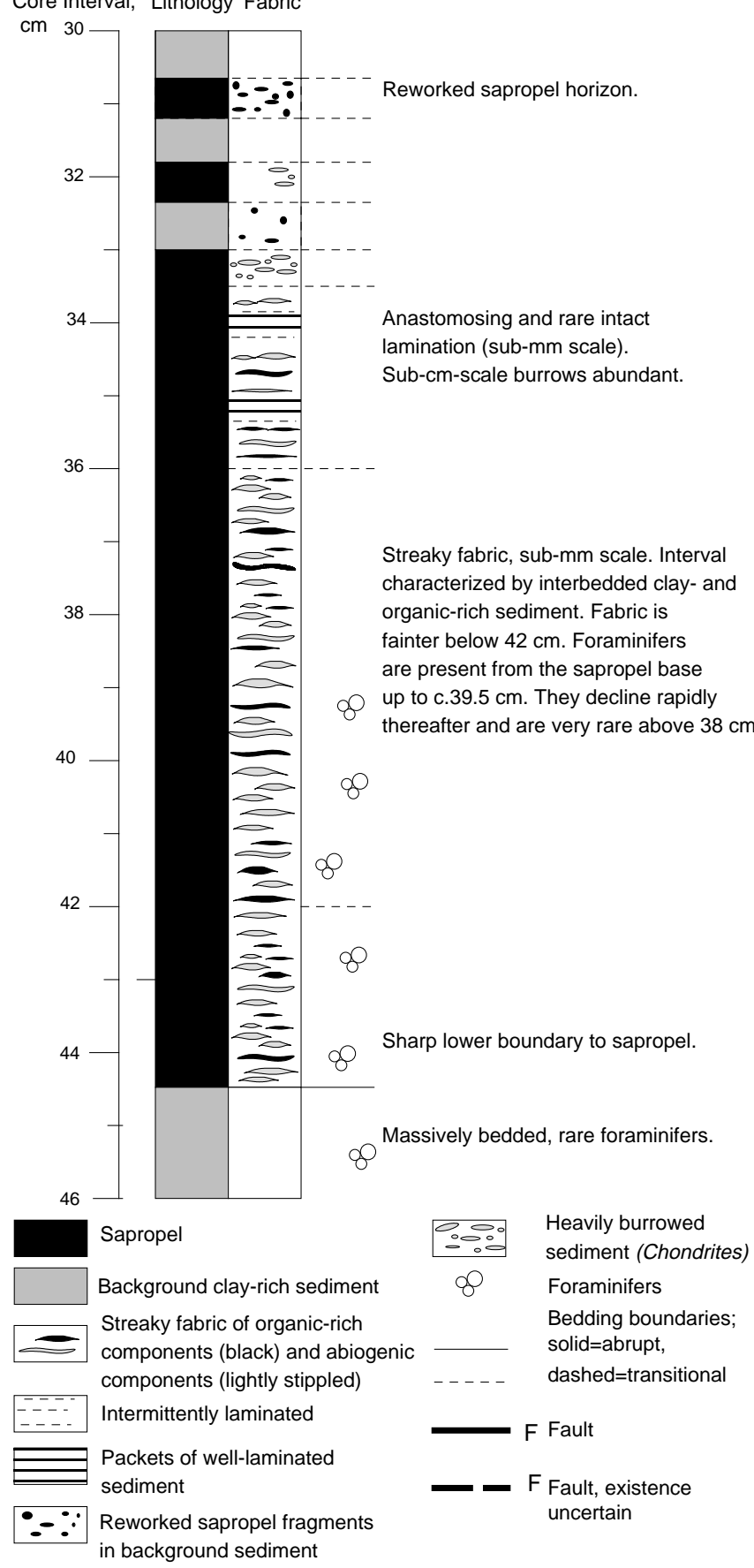

Figure 2. Summary log of the microfabrics in the "e" bed at Site 967 (interval 160-967C-6H-2, 30-46 cm).

scale clay-rich/organic-rich laminae. They are overlain by a layer containing submillimeter irregular, discontinuous laminae with a thin middle zone of more intact laminae comprising 10 - to $25-\mu$ m-thick terrigenous sublaminae, predominantly of clay with minor silt intercalated with $\sim 10-\mu \mathrm{m}$-thick organic-rich laminae with pyrite.

\section{Bioturbated Sapropels}

Sapropels that did not contain pervasive millimeter- or submillimeter scale lamination show a range of bioturbation features, but some also contain evidence of layering or isolated lamina-scale com- 
Core Interval: 160-969D-5H-2, 40-76 cm Core Interval, Lithology Fabric

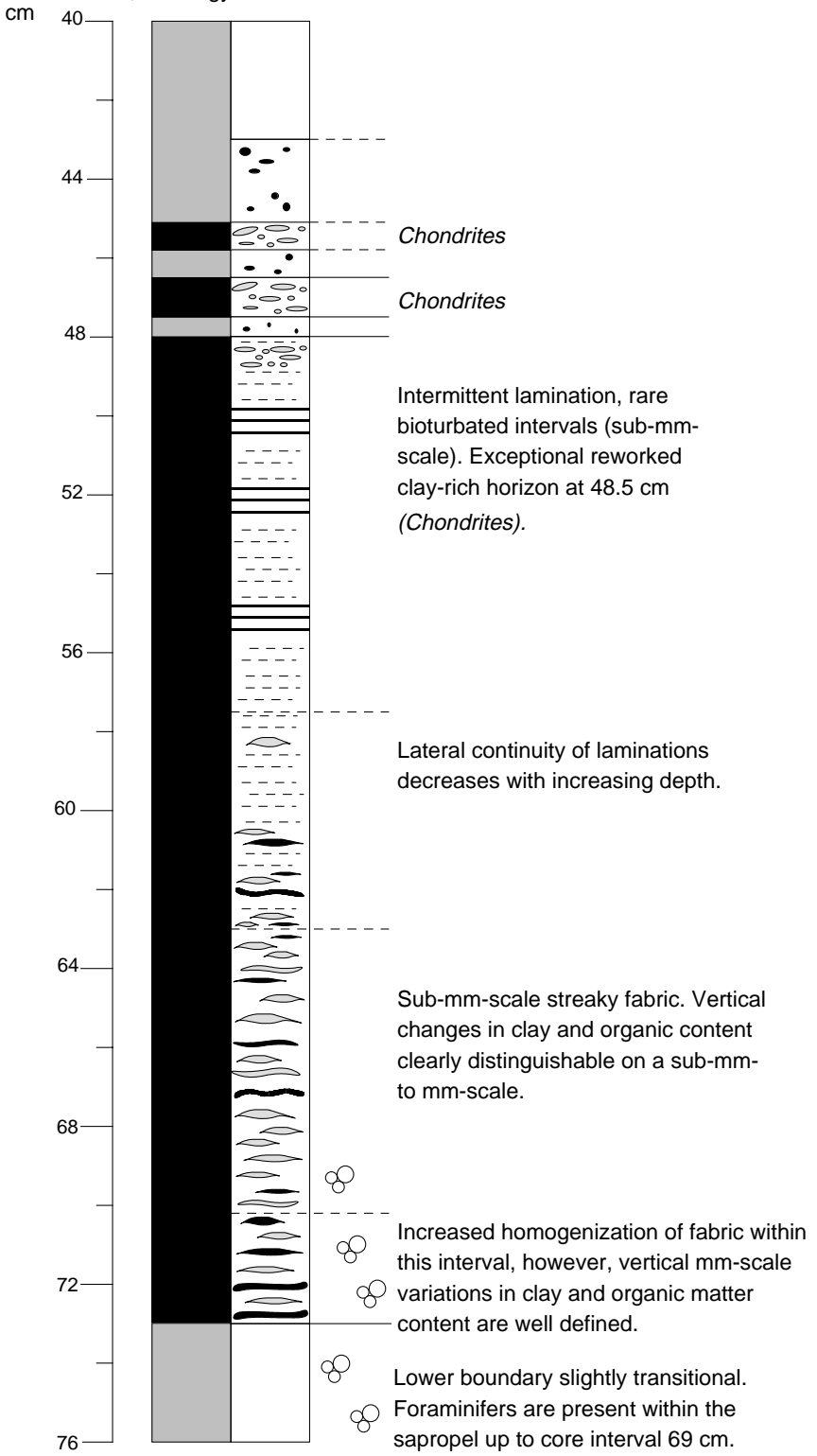

Figure 3. Summary log of the microfabrics in the "e" bed at Site 969 (interval 160-969D-5H-2, 40-76 cm). See Figure 2 for symbol explanations.

positional variation ( $\mathrm{Pl} .1,2,5)$. One sapropel (S5 at Hole 971A) that was examined proved to possess an excellent example of Chondrites (Pl. 2, Fig. 5)

Based upon BSEI examination, Sapropel S5 at Site 967 appears to be homogenous other than for occasional intercalated thin beds or laminae of gray silty clay and silt (Pl. 1). Some of these display grading (Pl. 1), which provides important evidence that they represent density current deposits rather than an interruption to the conditions associated with sapropel deposition and formation. Interestingly, despite the lack of laminae, this horizon does contain diatoms (described in detail below) together with radiolarians, foraminifers, and calcareous nannofossils.

The basal Pliocene sapropel that rests on Lago Mare facies calcareous silty clay in Hole 969B (Pl. 5) is essentially unlaminated on a submillimeter scale, other than for distinctive layers that are abundant in foraminifers. Other sapropels that were homogenized by bioturbation are listed in Table 1.
Core Interval: $160-969 \mathrm{E}-6 \mathrm{H}-6,24-48 \mathrm{~cm}$ Core Interval, Lithology Fabric

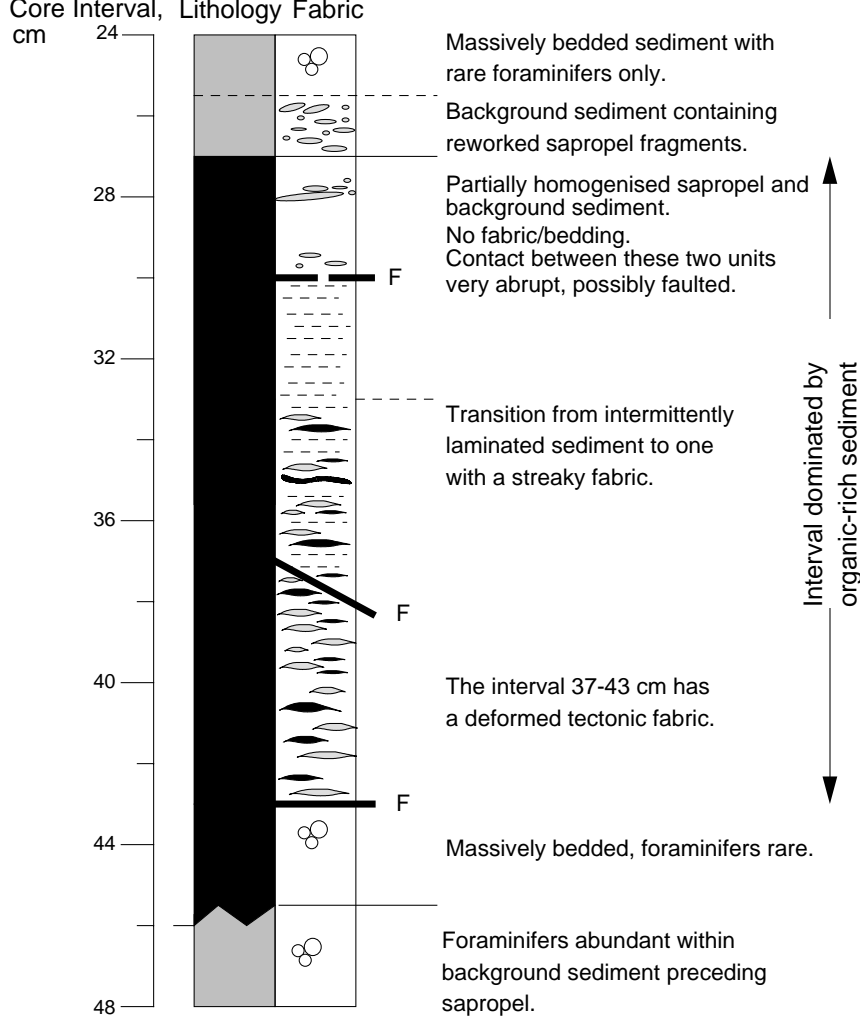

Figure 4. Summary log of the microfabrics in an "O" group sapropel at Site 969 (interval 160-969E-6H-6, 24-48 cm). See Figure 2 for symbol explanations.

\section{SUMMARY AND DISCUSSION}

\section{Lamina Composition}

The principal lamina-forming compositional end members encountered are (1) terrigenous sediment (mainly silty clay or clay); (2) organic matter (with pyrite); and (3) diatoms (Table 3). Opal dissolution is clearly a major factor in modifying the original depositional fabrics. Within the S5 sapropel in the moat of the Napoli mud volcano (described in detail in Pearce et al., Chap. 28, this volume), diatom preservation is excellent, and delicate opaline features are preserved (Pl. 2, Fig. 1). Within the "e" bed at Site 969, however, there is considerable dissolution of diatoms with absence of the delicately silicified part of the valve and girdle bands of rhizosolenids and etching of centric diatoms (Pl. 2, Fig. 2). In this bed, laminae comprising different species cannot be identified, probably because of the extensive dissolution of rhizosolenids. By contrast, in the correlative " $e$ " bed at Site 967, there are no diatoms preserved at all, and the fabric merely comprises an alternation of terrigenous silty clay and organic carbonrich material ( $\mathrm{Pl} .3)$. The relative proportion of organic material and terrigenous silty clay clearly varies both within and between beds with organic laminae occasionally thicker than terrigenous silty clay laminae (e.g., Pl. 2, Fig. 3).

\section{Implications of Lamina Preservation and Variation in Bioturbation}

Within the variably laminated sapropels described, distinct patterns of disruption emerge. In general, laminae are progressively better preserved towards the middle or upper parts of sapropels, but the topmost intervals are disrupted by burrowing (mainly Chondrites) that originated from levels of sediment deposited above the sapropel 
Core Interval: 160-964E-6H-4, 114-122 cm Core Interval, Lithology Fabric

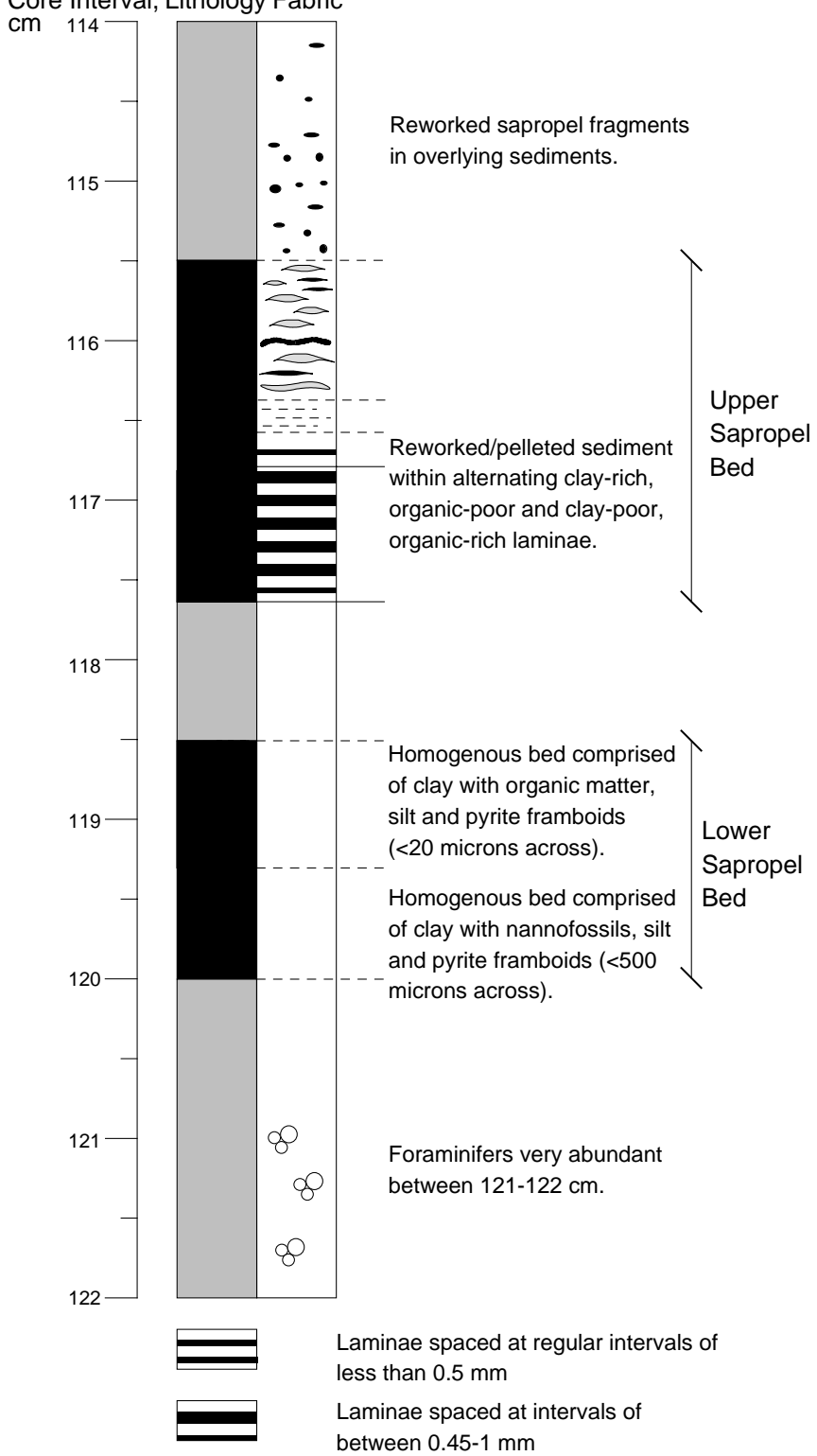

Figure 5. Summary log of the microfabrics in Sapropel 55 at Site 964 (interval 160-964E-6H-4, 114-122 cm). See Figure 2 for symbol explanations.

horizon itself. We interpret the more discontinuous or pelletized laminae to represent the minor bioturbative disruption of a low-oxygentolerant meiofauna (Brodie and Kemp, 1995). A provisional interpretation would be that bottom-water conditions during sapropel deposition became progressively more uniformly or persistently anoxic such that eventually all bottom-dwelling fauna perished. Following a return to more oxygenated bottom-water conditions, a macrofauna including Chondrites burrowed down into the sediment, in some cases disrupting only the topmost layers of the sapropel (Figs. 2, 3, 4), but in others pervasively disrupting the entire bed (Pl. 2, Fig. 5).

\section{Characterization of Organic Matter}

The BSEI and light-element X-ray mapping show that the organic matter is concentrated in separate laminae, or sublaminae, or may be associated with diatoms. In some cases, structured plant debris is observed (e.g., Pl. 4, Fig. 2). The appreciable S content of the organicrich areas (Pl. 3, Fig. 5; Pl. 4, Fig. 5) suggests a significant terrigenous component in these layers.

Palynofacies analysis was undertaken on material from the Site 969 "e" bed (Table 4). Following removal of abundant AOM of probable marine origin, significant structured kerogen components are present. The most abundant component are the bisaccate pollen grains at almost $200,000 \mathrm{~g}^{-1}$ of sediment. Other terrestrially sourced components are also abundant, which reflect either actual input, increased preservation potential from sedimentation with significant amounts of AOM, or a reduced clastic sediment input. The latter can be discounted, because bisaccate pollen grains are only transported and concentrated in the sedimentary environment by fluvial processes. Hence, significant numbers in the marine environment signify a fluvial terrestrial source and inevitably associated clastic input.

The abundance of leiospheres is a notable feature. The controls on the occurrence of leiospheres (essentially prasinophyte algae) have been the subject of much discussion with claims (Tyson, 1995) of them being both typical of anoxic basinal facies and brackish surfacewater conditions. In this instance, their association with a significant influx of bisaccate pollen, which indicates a distal terrestrial source, could be interpreted as demonstrating a significant brackish water influx. Extending this conclusion suggests that this sapropel is associated with and could result from an increased terrestrial sediment input into the environment.

\section{Significance of Diatom Species Composition and Opal Dissolution}

The diatom floras within the "e" bed of Site 969 and the S5 sapropel at Site 967 are similar: both are dominated by rhizosolenid diatoms, notably Pseudosolenia calcar-avis (Table 5). This species is characteristic of the stratified, nutrient-poor conditions during the summer months in the Mediterranean (Margalef, 1967). They may also form concentrations where nutrients are trapped at depth (see fuller discussion in Pearce et al., Chap. 28, this volume). The other diatoms include abundant Chaetoceros spp. and Thalassionema spp., both of which characterize seasonal blooms (Ignatiades, 1969) as well as the bloom driven by input of floodwater from the Nile river (before the Aswan Dam; Halim et al., 1967). Thus, the diatom species composition provides evidence both for periods of stratification and periods of turnover or nutrient input. The differences in abundance of diatoms between the two horizons (Table 5) probably results, at least in part, from greater opal dissolution within the S5 sapropel at Site 967.

The presence of diatoms in the "e" bed at Site 969 and their absence at the equivalent sapropel at Site 967 is best explained by dissolution of original opal at Site 967 . The intermittent presence of diatoms in sapropels at Site 969 may reflect its position on the complex topography of the Mediterranean Ridge. Although opal is not preserved in recent sediments elsewhere in the Mediterranean, wellpreserved diatoms and radiolarians have been recovered from anoxic basins on the Mediterranean Ridge (Erba, 1991) where bottom waters contain elevated silica (De Lange et al., 1990), compared with the normal silica-poor Mediterranean waters (Krom et al., 1991). Given the active tectonics in the vicinity, the area now occupied at Site 969 may have intermittently acted as a mini-anoxic basin that served to prevent complete opal dissolution at some levels. Elsewhere at Site 971, the moat of the Napoli mud volcano probably fulfilled a similar role (see Pearce et al., Chap. 28, this volume).

\section{CONCLUSIONS}

Sapropels from the Eastern Mediterranean possess a broad range of fabrics ranging from well laminated to pervasively bioturbated. 
Table 3. Summary of occurrence of lamina types and composition.

\begin{tabular}{|c|c|c|c|c|c|}
\hline \multirow{2}{*}{$\begin{array}{l}\text { Lamina types and } \\
\text { associations }\end{array}$} & \multicolumn{2}{|c|}{ Lamina components } & \multirow{2}{*}{$\begin{array}{l}\text { Thickness range } \\
\qquad(\mu \mathrm{m})\end{array}$} & \multirow[b]{2}{*}{ Lamina continuity } & \multirow[b]{2}{*}{ Examples (intervals given in $\mathrm{cm}$ ) } \\
\hline & Dominant $(>50 \%)$ & Minor $(>25 \%)$ & & & \\
\hline Diatom ooze & $\begin{array}{l}\text { Near-monospecific diatom assemblage } \\
\text { of Rhizosolenids }\end{array}$ & $\begin{array}{l}\text { Other diatom genera, e.g., } \\
\text { Thalassionema spp., rare } \\
\text { nannofossils and clays }\end{array}$ & $50-1500$ & Greater than $1 \mathrm{~cm}$ & Sapropel S5 at $971 \mathrm{C}-2 \mathrm{H}-3,80-130$ \\
\hline Diatom ooze & $\begin{array}{l}\text { Mixed diatom assemblage, e.g., } \\
\text { Rhizosolenids, Thalassionema spp. }\end{array}$ & Nannofossils and clays & $15-700$ & Greater than $1 \mathrm{~cm}$ & \\
\hline Diatom ooze & $\begin{array}{l}\text { Mixed diatom assemblage, e.g., } \\
\text { Rhizosolenids, Thalassionema spp. }\end{array}$ & Nannofossils and clays & $15-700$ & Greater than $1 \mathrm{~cm}$ & Sapropel S5 at $971 \mathrm{C}-2 \mathrm{H}-3,80-130$ \\
\hline Terrigenous & Clay & Silt and rare diatoms & $0.1-5 \mathrm{~mm}$ & Greater than $1 \mathrm{~cm}$ & \\
\hline Diatom ooze & $\begin{array}{l}\text { Mixed diatom assemblage, e.g., } \\
\text { Rhizosolenids, Thalassionema clays } \\
\text { spp., and Chaetoceros spp. }\end{array}$ & Silicoflagellates and Clays & $25-75$ & Less than $100 \mu \mathrm{m}$ to c. $1 \mathrm{~mm}$ & $\begin{array}{l}\text { Sapropel } 47 \text { ("e" bed) at 969D-5H-2, } \\
\quad 42-76\end{array}$ \\
\hline Silty-Clay & Clay & F. silt & $<10-30$ & Less than $100 \mu \mathrm{m}$ to $\mathrm{c} .1 \mathrm{~mm}$ & \\
\hline Organic & Organic matter & Nannofossils & $<5-30$ & Less than $100 \mu \mathrm{m}$ to c. $1 \mathrm{~mm}$ & \\
\hline Silty-Clay & Clay & Silt and nannofossils & $<100$ & Less than $100 \mu \mathrm{m}$ to $\mathrm{c} .1 \mathrm{~mm}$ & $\begin{array}{l}\text { Sapropel } 47 \text { ("e" bed) at 967C-6H-2, } \\
30-46\end{array}$ \\
\hline Clay & Clay & & $<75$ & Less than $100 \mu \mathrm{m}$ to c. $1 \mathrm{~mm}$ & \\
\hline Organic & Organic matter & & $<10-75$ & $100-200 \mu \mathrm{m}$ to several mm & \\
\hline Silty-Clay & Clay & $\begin{array}{l}\text { F. silt } \\
\text { Nannofossils }\end{array}$ & c. $5-25$ & $\begin{array}{l}\text { Less than } 100 \mu \mathrm{m} \text { to several } \\
\qquad 100 \mu \mathrm{m}\end{array}$ & $\begin{array}{c}\text { Sapropels } 55 \text { and } 71 \text { at } 964 \mathrm{E}-6 \mathrm{H}-4 \text {, } \\
108-124 \text { and } 969 \mathrm{E}-6 \mathrm{H}-6,23-41 /\end{array}$ \\
\hline Organic & Organic matter & Spores & $<10-25$, (rarely) & $\begin{array}{l}\text { Less than } 100 \mu \mathrm{m} \text { to several } \\
\qquad 100 \mu \mathrm{m}\end{array}$ & $969 \mathrm{~A}-7 \mathrm{H}-1,14-27$ \\
\hline Foraminifer & Foraminifers & Clay & c. 500 & Greater than $1 \mathrm{~mm}$ & Basal Pliocene sapropel at 969B-11H- \\
\hline & Pyrite framboids & & $<50-500$ & Greater than $1 \mathrm{~mm}$ & $6,121-128$ \\
\hline
\end{tabular}

Table 4. Palynofacies analysis results.

\begin{tabular}{|c|c|c|c|}
\hline $\begin{array}{c}\text { Kerogen } \\
\text { component }\end{array}$ & Hole $969 \mathrm{E}_{\mathrm{P} 14}$ & Percent & Absolute \\
\hline Light wood & 8 & 2.0 & 7200 \\
\hline Dark wood & 4 & 1.0 & 3600 \\
\hline Bisaccate pollen & 212 & 53.0 & 189900 \\
\hline Dinocyst sp 1 & 18 & 4.5 & 16100 \\
\hline Dinocysts others & 59 & 14.7 & 52900 \\
\hline Microforaminifers & 0 & 0 & 0 \\
\hline Spores \& pollen & 2 & 0.5 & 1800 \\
\hline Cuticle & 0 & 0 & 0 \\
\hline Leiospheres & 97 & 24.2 & 86900 \\
\hline Lycopodium & 14 & & \\
\hline Total structured $\mathrm{g}^{-1}$ & & & 370900 \\
\hline
\end{tabular}

Evidence from laminated sapropels indicates that bottom waters became more uniformly anoxic during sapropel deposition.

SEM microfabric studies show that some thin interbeds within sapropels represent genuine interruptions to sapropel deposition, whereas other beds or laminae are clearly the deposits of sediment gravity flows.

Relatively few sapropels contain preserved opal, although diatoms do occur in bioturbated sapropels as well as laminated sapropels. It is suggested that diatoms were an important component of most sapropels and that original lamina fabrics included separate diatom laminae. Subsequent, postdepositional, early diagenetic opal dissolution reduced the thickness of sapropel beds and left a "remnant" lamina fabric of alternating organic-carbon and terrigenous, silty-clay laminae.

Evidence from diatom species composition and from palynofacies analysis supports a model of sapropel formation involving regular fresh-water, terrigenous sediment and nutrient input from the Nile, which led to stratification with a relatively lower salinity surface layer.

\section{ACKNOWLEDGMENTS}

The contributions of RBP and AESK were supported by funding under the UK ODP/NERC Science Programme, Grant GST/02/1099, and JP acknowledges support from an ODP/NERC Research Fellowship (GT5/95/ODP/3). The referees are thanked for their comments.

\section{REFERENCES}

Bishop, A.N., Kearsley, A.T., and Patience, R.L., 1992. Analysis of sedimentary organic materials by scanning electron imagery and light element $\mathrm{X}$ ray microanalysis. Org. Geochem., 18:431-446.

Bodén, P., 1991. Reproducibility in the random settling method for quantitative diatom analysis. Micropaleontology, 37:313-319.

Brodie, I., and Kemp, A.E.S., 1995. Pelletal structures in Peru upwelling sediments. J. Geol. Soc. London, 152:141-150.

De Lange, G.J., Middelburg, J.J., Van der Weijden, C.H., Catalano, G., Luther, G.W., Hydes, D.J., Woittez, J.R.W., and Klinkhammer, G.P., 1990. Composition of anoxic hypersaline brines in the Tyro and Bannock Basins, eastern Medterranean. Mar. Chem., 31:63-88.

Erba, E., 1991. Deep mid-water bacterial mats from anoxic basins of the Eastern Mediterranean. Mar. Geol., 100:83-101.

Halim, Y., Guerges, S.K., and Saleh, H.H., 1967. Hydrographic conditions and plankton in the South East Mediterranean during the last normal Nile flood (1964). Int. Rev. Ges. Hydrobiol., 52:401-425.

Hilgen, F.J., 1991. Astronomical calibration of Gauss to Matuyama sapropels in the Mediterranean and implication for the geomagnetic polarity time scale. Earth Planet. Sci. Lett., 104:226-244.

Ignatiades, L., 1969. Annual cycle, species diversity and succession of phytoplankton in lower Saronicos Bay, Aegean Sea. Mar. Biol., 3:196-200.

Krom, M.D., Brenner, S., Israilov, L., and Krumgalz, B., 1991. Dissolved nutrients, preformed nutrients and calculated elemental ratios in the South-East Mediterranean Sea. Oceanol. Acta, 14:189-194.

Lange, C.B., and Berger, W.H., 1993. Diatom productivity and preservation in the western equatorial Pacific: the Quaternary record. In Berger, W.H., Kroenke, L.W., Mayer, L.A., et al., Proc. ODP, Sci. Results, 130: College Station, TX (Ocean Drilling Program), 509-523.

Laws, R.A., 1983. Preparing strewn slides for quantitative microscopical analysis: a test using calibrated microspheres. Micropaleontology, 29:6065.

Macquaker, J.H.S., and Gawthorpe, R.L., 1993. Mudstone lithofacies in the Kimmeridge Clay Formation, Wessex Basin, southern England: implications for the origin and controls on the distribution of mudstones. J. Sediment. Petrol., 63:1129-143.

Margalef, R., 1967. The food web in the pelagic environment. Helg. Wiss. Meeresunters., 15:548-559. 
Pedersen, T.F. and Calvert S.E., 1990.Anoxia vs. productivity: what controls the formation of organic-carbon-rich sediments and sedimentary rocks? Am. Assoc. Petrol. Geol. Bull. 74:454-466.

Pike, J., and Kemp, A.E.S., 1996. Preparation and analysis techniques for studies of laminated sediments. Geol. Soc. Spec. Publ. London, 116:3748.

Schrader, H.J., and Gersonde, R., 1978. Diatoms and silicoflagellates. Utrecht Micropaleontol. Bull., 17:129-176.

Schrader, H.J., and Matherne, A., 1981. Sapropel formation in the eastern Mediterranean sea: evidence from preserved opal assemblages. Micropaleontology, 27:191-203.
Stockmarr, J., 1971. Tablets with spores used in absolute pollen analysis. Pollen et Spores, 13:615-621.

Tyson, R.V., 1995. Sedimentary Organic Matter: Organic Facies and Palynofacies: London (Chapman \& Hall).

Date of initial receipt: 24 January 1997

Date of acceptance: 19 June 1997

Ms 160SR-068

Table 5. Diatom species composition and abundance.

\begin{tabular}{|c|c|c|c|}
\hline Hole, core, section, interval $(\mathrm{cm})$ : & $969 \mathrm{E}-5 \mathrm{H}-2,53-54$ & $969 \mathrm{E}-5 \mathrm{H}-2,49-50$ & $967 \mathrm{~B}-2 \mathrm{H}-1,124-125$ \\
\hline Actinocyclus spp. & 3 & 2 & 2 \\
\hline Actinoptychus sp. & 1 & 1 & 4 \\
\hline Asterolampra marylandica Ehrenberg & 2 & 10 & 8 \\
\hline Asteromphalus flabellatus (Brebisson) Greville & & 4 & \\
\hline Asteromphalus robustus Castracane & & 1 & 1 \\
\hline Azpeitia sp. & 2 & 1 & \\
\hline Bacteriastrum furcatum Shadbolt & 1 & 2 & 1 \\
\hline Coscinodiscus radiatus Ehrenberg & 5 & & \\
\hline Coscinodiscus spp. & 2 & 1 & 2 \\
\hline Ditylum sp. & & 1 & 2 \\
\hline Grammatophora sp. & & & 3 \\
\hline Hemiaulus hauckii Grunow & 2 & & 2 \\
\hline Hemidiscus cuneiformis Wallich & 6 & 2 & \\
\hline Melosira sp. & & 1 & \\
\hline Navicula sp. & & & \\
\hline Nitzschia marina Grunow & 2 & & \\
\hline Nitzschia spp. & 1 & 2 & 2 \\
\hline Proboscia alata (Brightwell) Simonsen & & 1 & \\
\hline Pseudosolenia calcar-avis (Schultze) Simonsen & 57 & 56 & 333 \\
\hline Rhizosolenia bergonii Peragallo & 2 & 4 & 5 \\
\hline Rhizosolenia setigera Brightwell & 6 & & \\
\hline Rhizosolenia styliformis Brightwell & 188 & 246 & 3 \\
\hline Thalassionema bacillaris (Heiden) Kolbe & & 2 & 1 \\
\hline Thalassionema frauenfeldii (Grunow) Hallegraeff & 13 & 15.5 & 12 \\
\hline Thalassionema nitzschioides Grunow & 6 & 9 & 15 \\
\hline Thalassiosira eccentrica (Ehrenberg) Cleve & 4 & & \\
\hline Thalassiosira lineata Jouse & 6 & & \\
\hline Thalassiosira oestrupii (Ostefeld) Proshina-Varenko & 99 & 54 & 1 \\
\hline Thalassiosira spp. & 9 & 4 & \\
\hline Thalassiothrix spp. & 4 & 3 & 4 \\
\hline Total valves counted (not including Chaetoceros spp. r. sp.) & 421 & 422.5 & 401 \\
\hline Chaetoceros spp. resting spores & 197 & 361 & 69 \\
\hline Dactyliosolen sp. girdle bands & 89 & 48 & 1 \\
\hline Diatom abundance $(10 * 8 / \mathrm{g})$ without Chaetoceros spp. r. sp. & 5.53 & 5.05 & 0.30 \\
\hline Diatom abundance $(10 * 8 / \mathrm{g})$ with Chaetoceros spp. r. sp. & 8.12 & 9.36 & 0.35 \\
\hline
\end{tabular}

Notes: $10^{*} 8 / \mathrm{g}=10^{8} / \mathrm{g}$. r.sp. $=$ resting spores. 


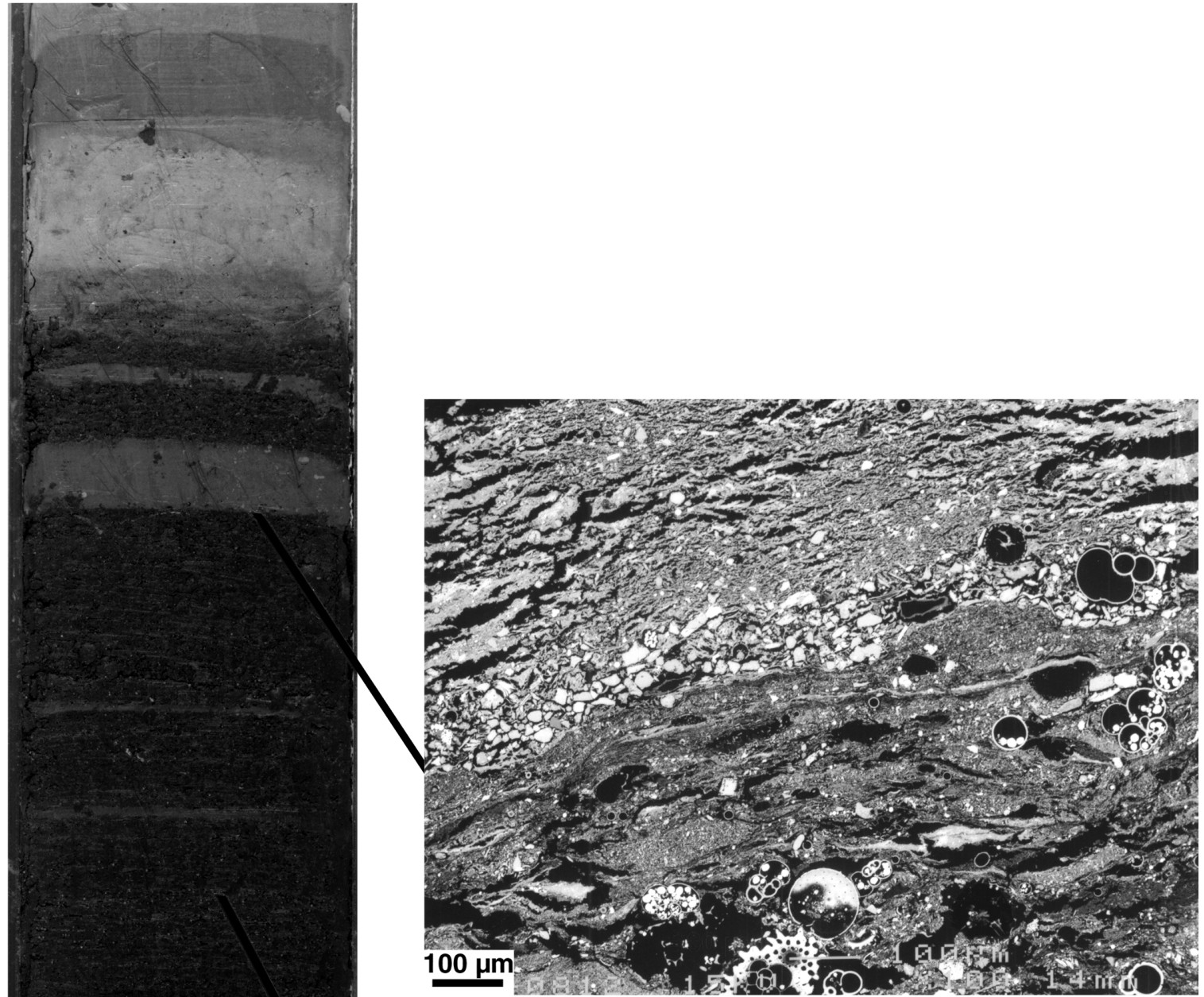

2

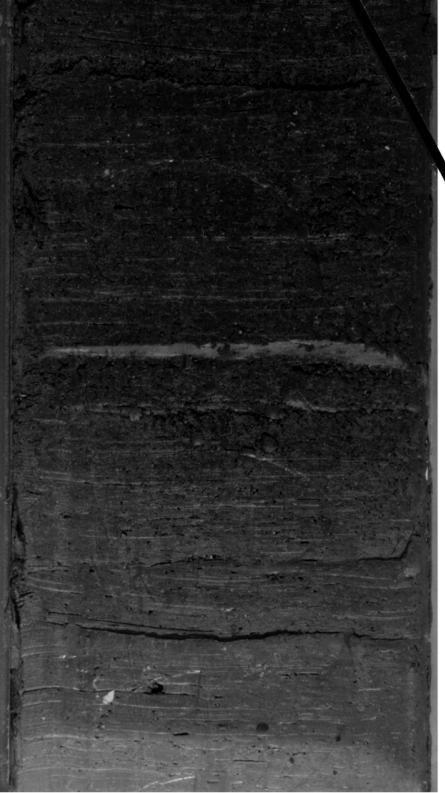

1

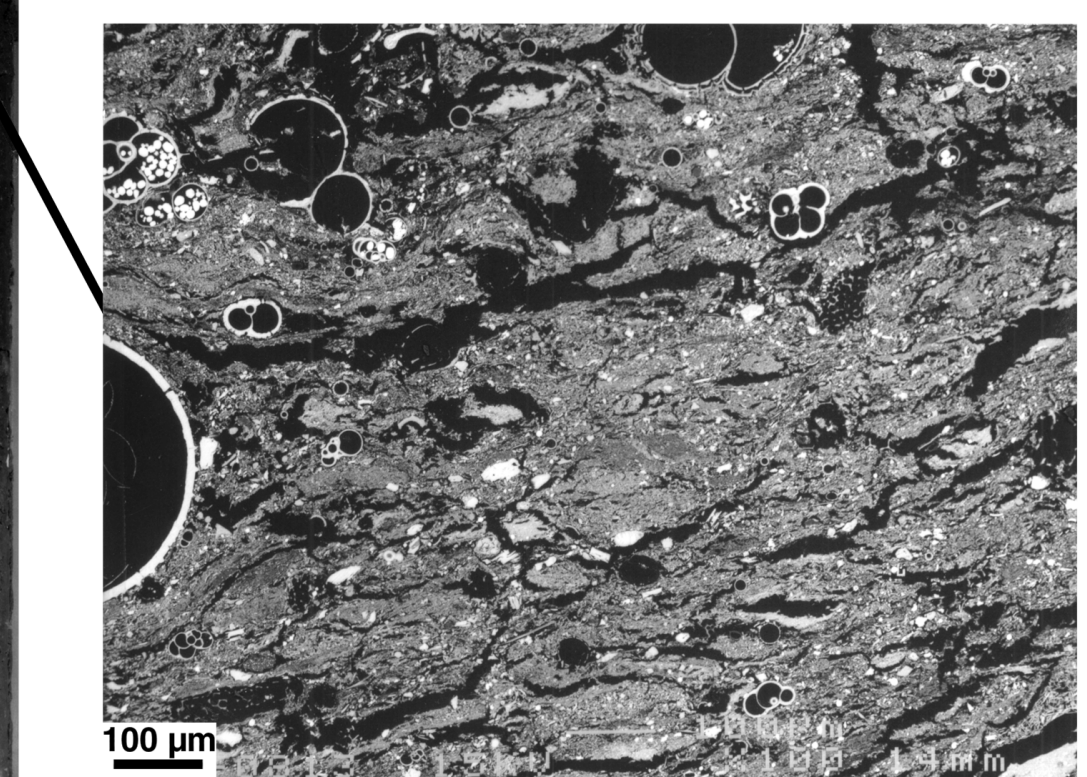

3

Plate 1. 1. Core photo of Sapropel S5 at Site 967 (interval 160-967B-2H-1, 104-138 cm). 2. BSEI of the erosional contact between a silty clay horizon and sapropel sediment (Sample 160-967B-2H-1, $114.5 \mathrm{~cm}$ ). The base of the silty clay contains abundant angular silt- and sand-sized clasts, and fines upwards. 3. BSEI of the sapropel. The sediment is well bioturbated and contains abundant planktonic foraminifers, some with pyrite framboids, and partially dissolved radiolarians. 


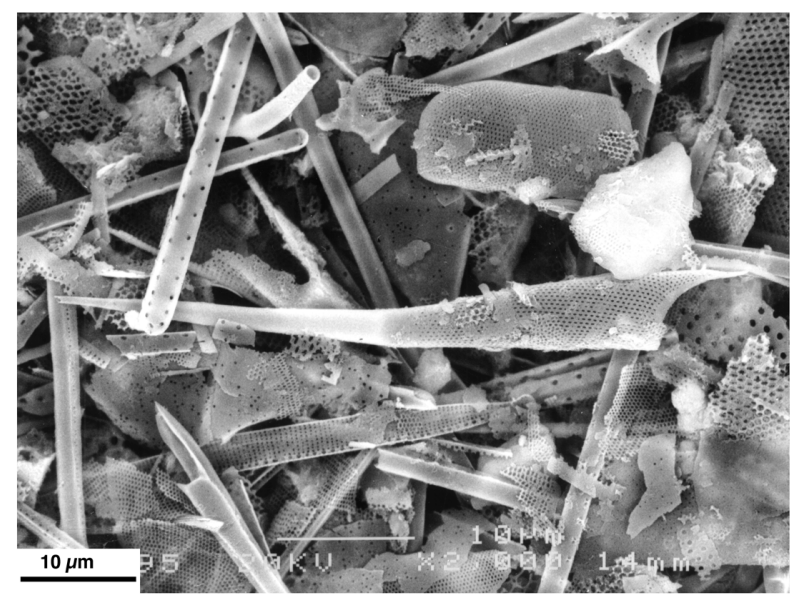

1

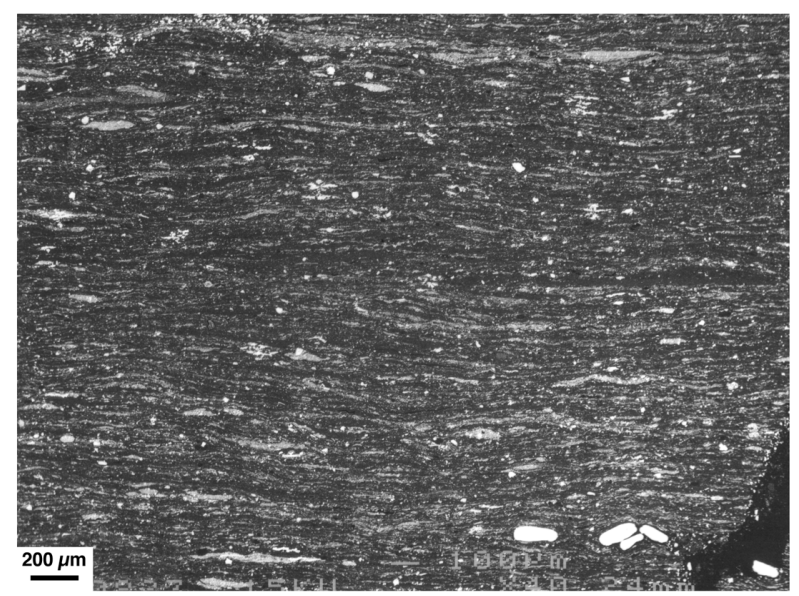

3

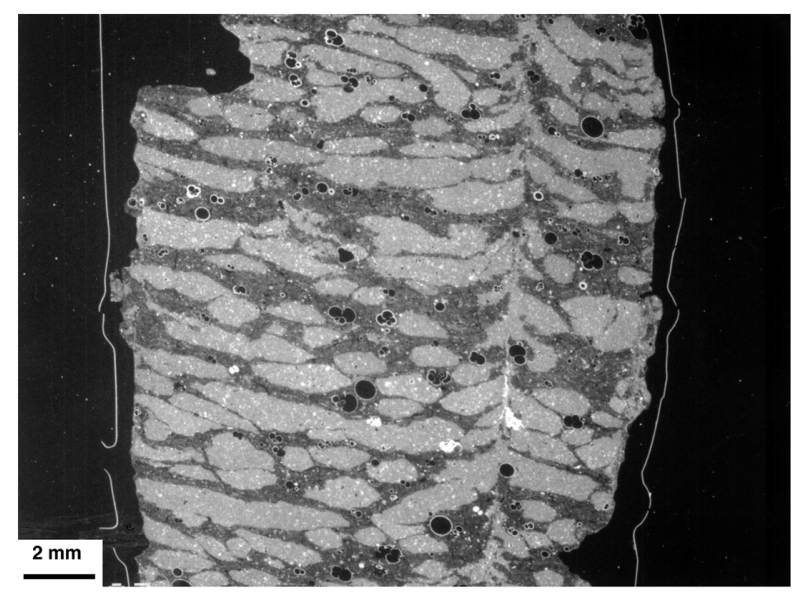

5

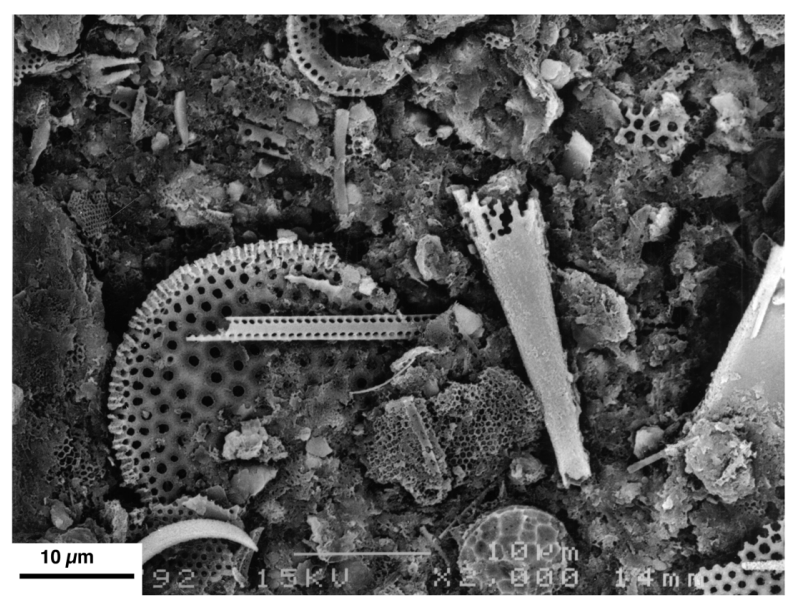

2

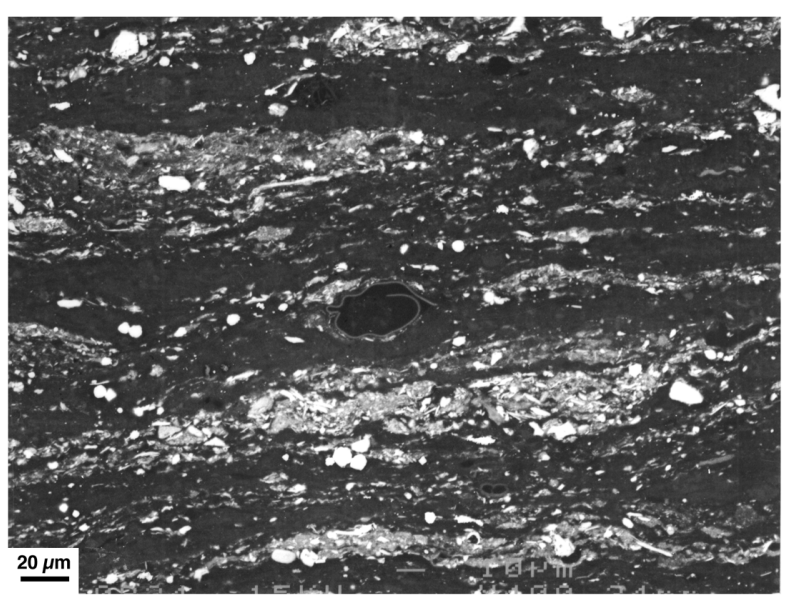

4

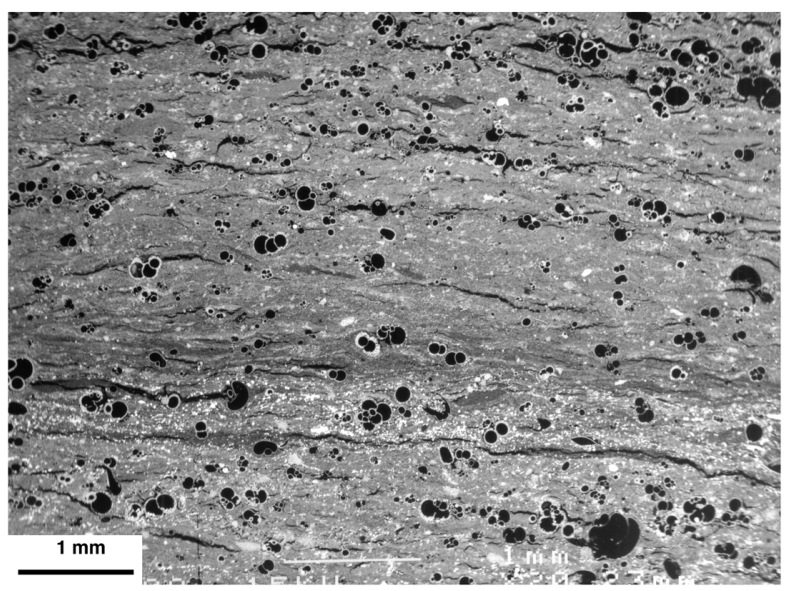

6

Plate 2. 1. This back-scatter electron (BSE) topographic image of a well-preserved rhizosolenid frustule shows the good state of preservation frequently observed in the laminated diatom ooze that is located in the moat of the mud volcano at Hole 971C (Sample 160-971C-2H-3, 126-129 cm). 2. BSE topographic image of etched diatom-rich sediment from the "e" bed (Pliocene Sapropel 47), Sample 160-969D-5H-2, 53-57.5 cm. 3. Lamina fabric of an "O" Group sapropel (Sample 160-969E-6H-6, 30.3-34.6 cm). The white-to light-gray BSEI tone sediment is comprised of clay and fine silt grains, and the dark-gray to black BSEI tone sediment is comprised of organic material. 4. High magnification BSEI of lamina fabric (Sample 160-969E-6H-6, 30.3-34.6 cm). A spore (probably) can be observed in the centre of the image. 5. Electronic channelling patter (ECP) BSEI of Chondrites burrow structure in Sapropel S5 at Hole 971A (Sample 160-971A-1H-3, 45-46 cm). 6. BSEI of nonlaminated sapropel (Sample 160-967D-2H-3, 94.5-104 cm). Note the abundance of planktonic foraminifers and the occurrence of pyrite framboids immediately below the gray BSEI tone interval, probably indicative of an increased abundance of organic matter. 
Intentionally blank. 
Plate 3. BSEI of lamina fabrics and X-ray map elemental data from the "e" bed, Site 967 (Sample 160-967B-6H-2, 33.5-36 cm). 1. Low magnification image of lamina fabric, showing the variation in preservation and lateral continuity of the laminae. Also note the abundance of terrigenous sediment (light BSEI tone) relative to organic-rich material (dark BSEI tone). 2. BSEI of area mapped for elements $\mathrm{C}, \mathrm{O}, \mathrm{Na}, \mathrm{Mg}, \mathrm{Al}, \mathrm{Si}, \mathrm{P}, \mathrm{S}, \mathrm{Cl}, \mathrm{K}, \mathrm{Ca}$, and Fe. Note the occurrence of discrete and groups of calcareous nannofossils within the organic-rich sediment, and the two types of terrigenous sediment, silty clays (dominant), and clays. $\mathbf{3}$. Elemental data for $\mathrm{Al}$, which highlights the terrigenous laminae and the angular silt grain (top, left corner). 4. Elemental data for $\mathrm{C}$. This shows the organic carbon-rich laminae, but also variations in porosity as evidenced by the organic resin used for sample impregnation. The terrigenous laminae are low in C. 5. Elemental data for S. The intense white spots are pyrite framboids; overprocessing has caused distortion of their true morphology. The organic-rich layers are shown by the light-gray tone, which indicates the presence of minor amounts of sulfur within these layers, and implies a terrestrial origin for them. 


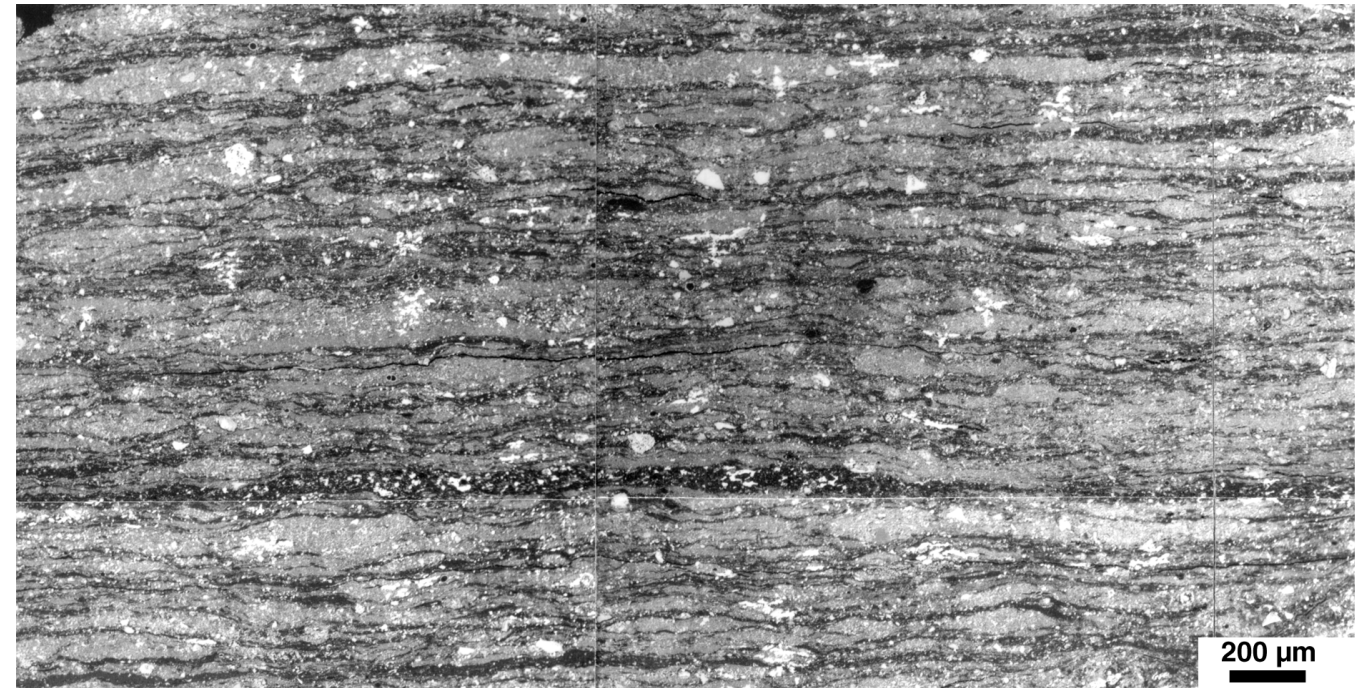
1

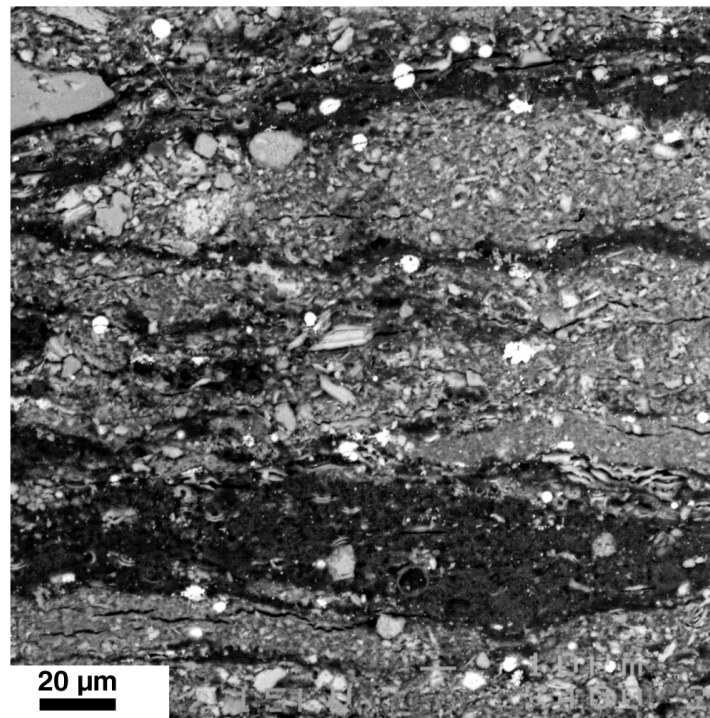

2

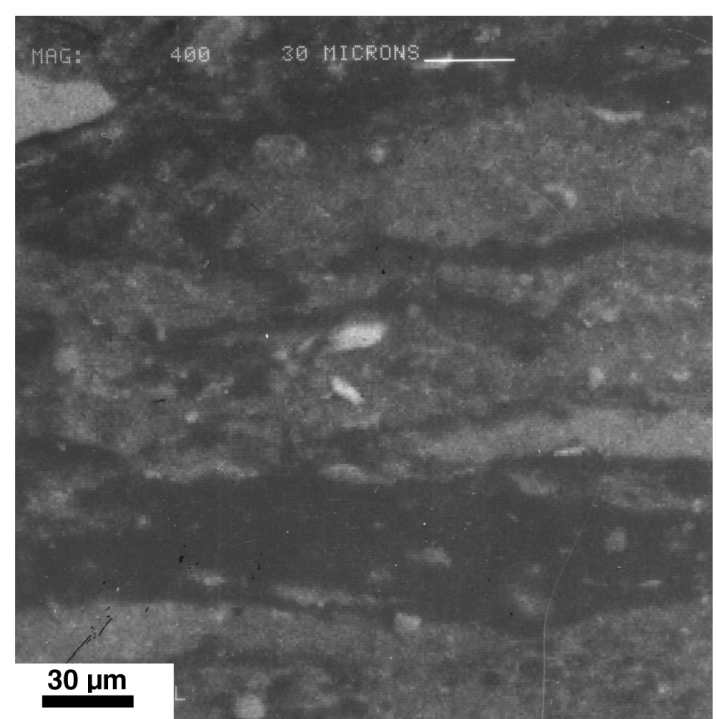

3
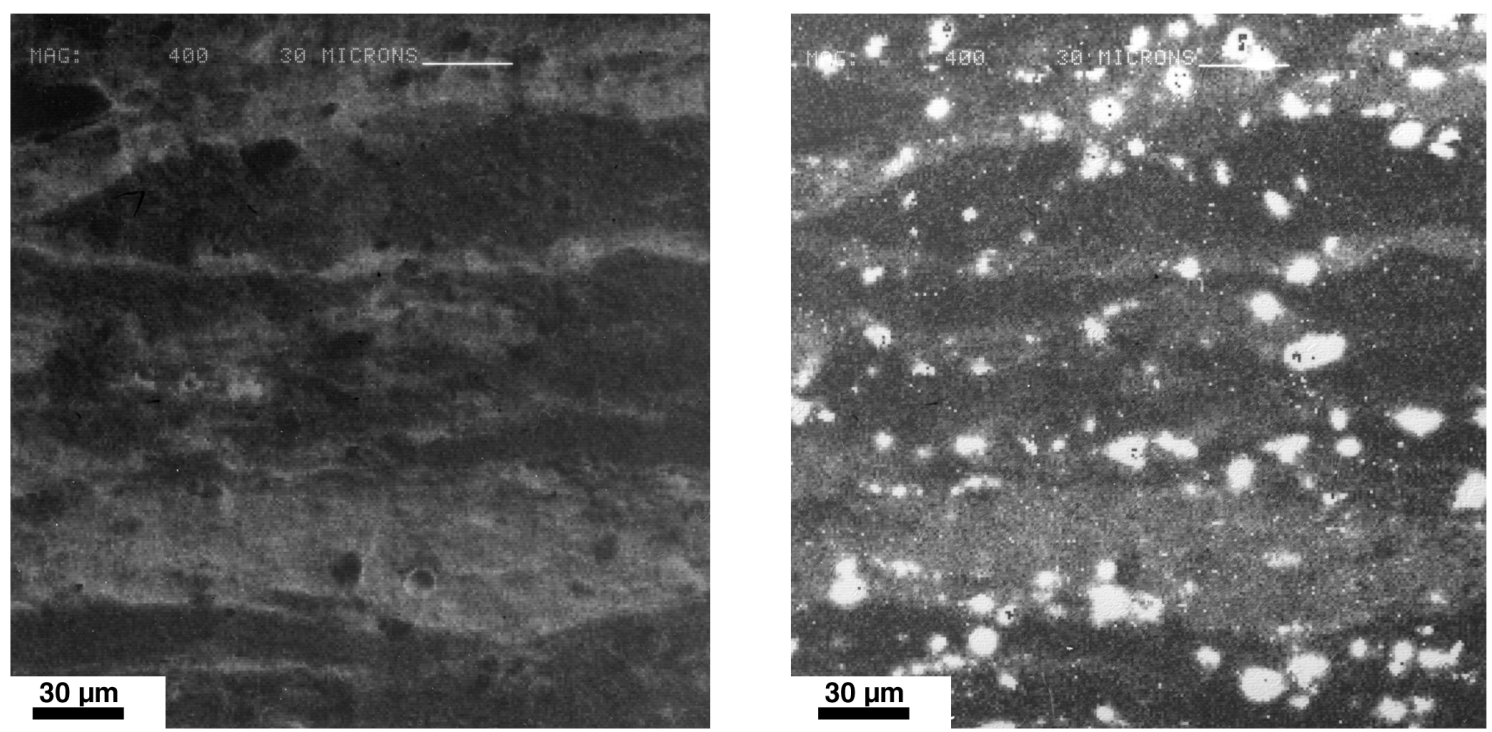

5 
Plate 4. BSEI of lamina fabrics and X-ray map elemental data from the "e" bed, Site 969 (Sample 160-969D-5H-2, 53-57.5 cm). 1. Low magnification image of lamina fabric, showing the lateral variability in lamina thickness. 2. BSEI of area mapped for elements $\mathrm{C}, \mathrm{O}, \mathrm{Na}, \mathrm{Mg}, \mathrm{Al}, \mathrm{Si}, \mathrm{P}, \mathrm{S}, \mathrm{Cl}, \mathrm{K}, \mathrm{Ca}$, and $\mathrm{Fe}$. Note the discontinuous nature of the terrigenous laminae, the abundance of diatom frustules within the dark BSEI tone intervals, and the occurrence of horizons within the dark BSEI tone intervals not containing any diatoms. 3. Elemental data for Al. The two main terrigenous intervals are easily observed, but two thin (sub-10 $\mu \mathrm{m})$ terrigenous horizons are apparent also. 4. Elemental data for $\mathrm{C}$ showing subtle variations in porosity between the terrigenous and nonterrigenous laminae. $\mathbf{5}$. Elemental data for S, showing that minor quantities of sulfur are present within the nondiatom-bearing, and dark BSEI tone sediment. The location of pyrite framboids are indicated by the intense white spots. 


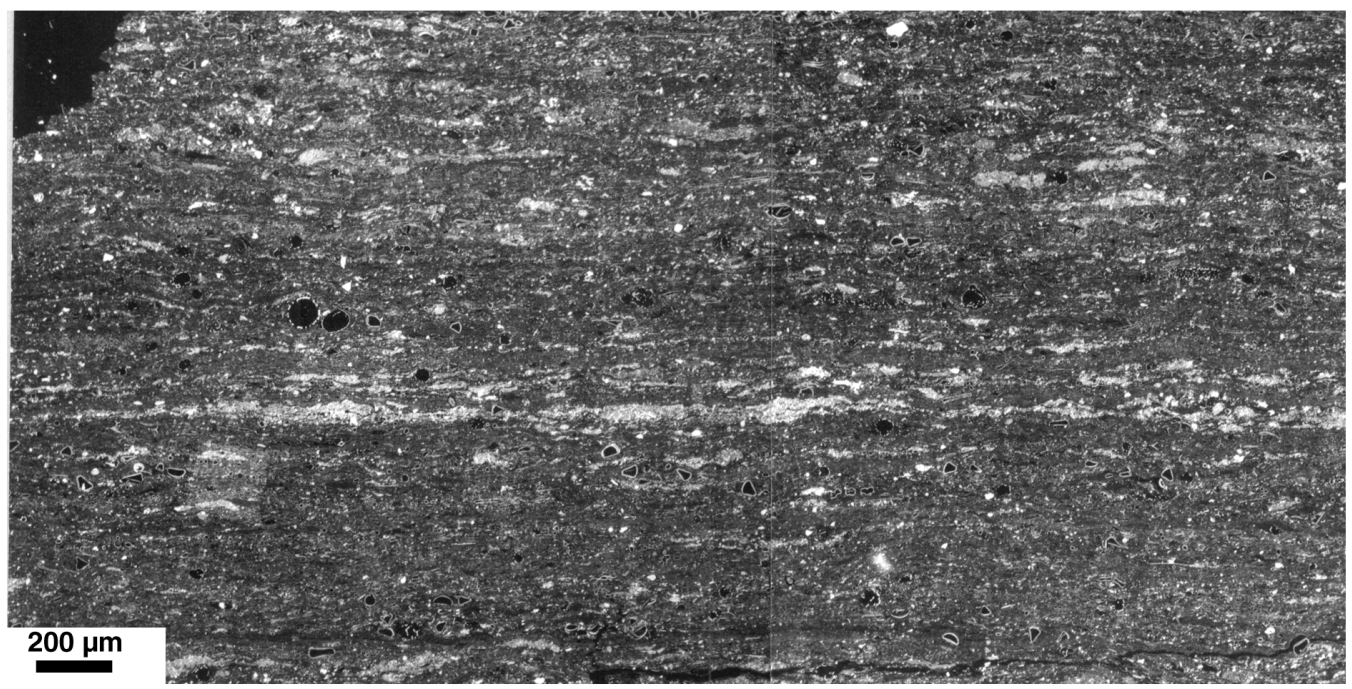

1
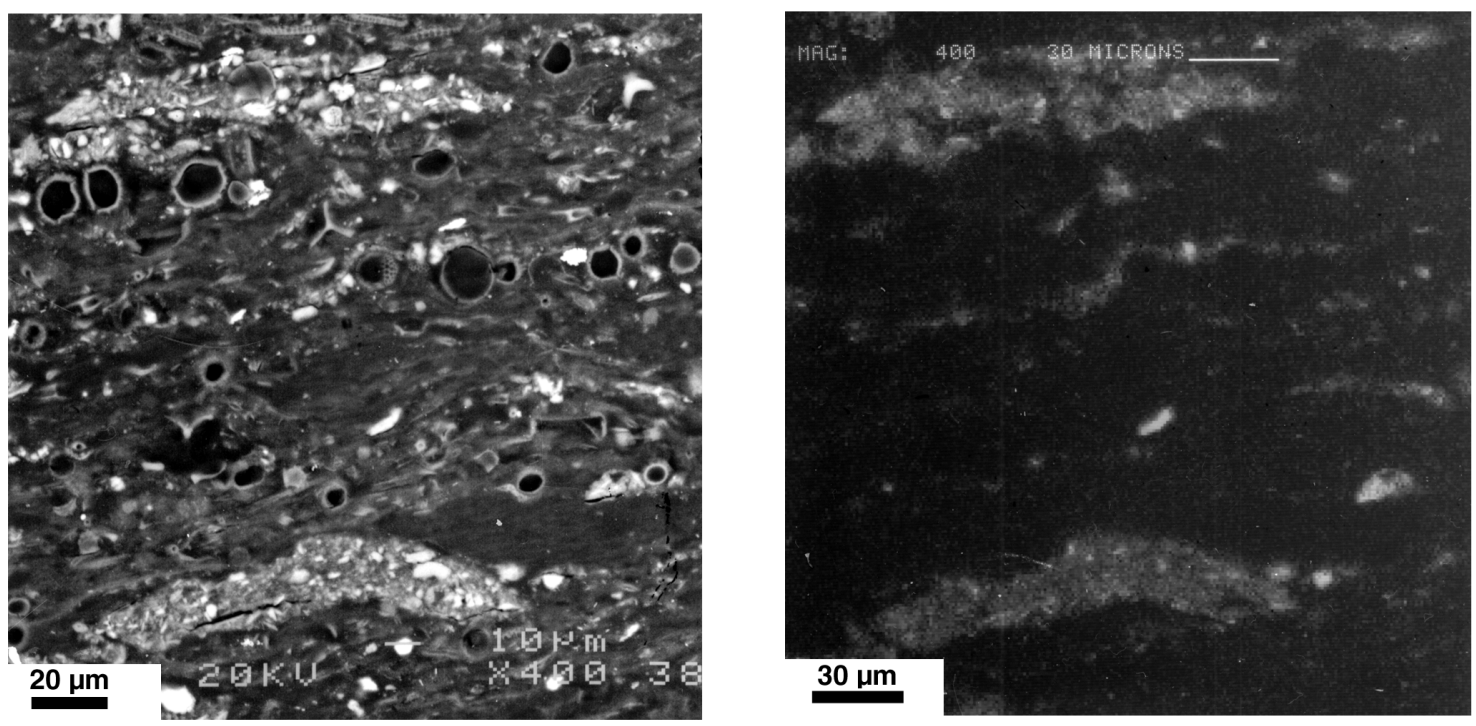

2

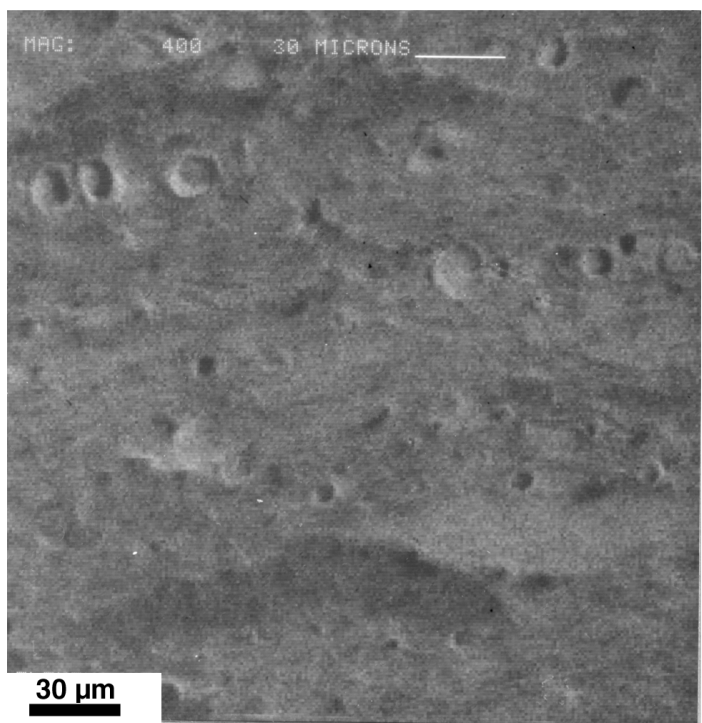




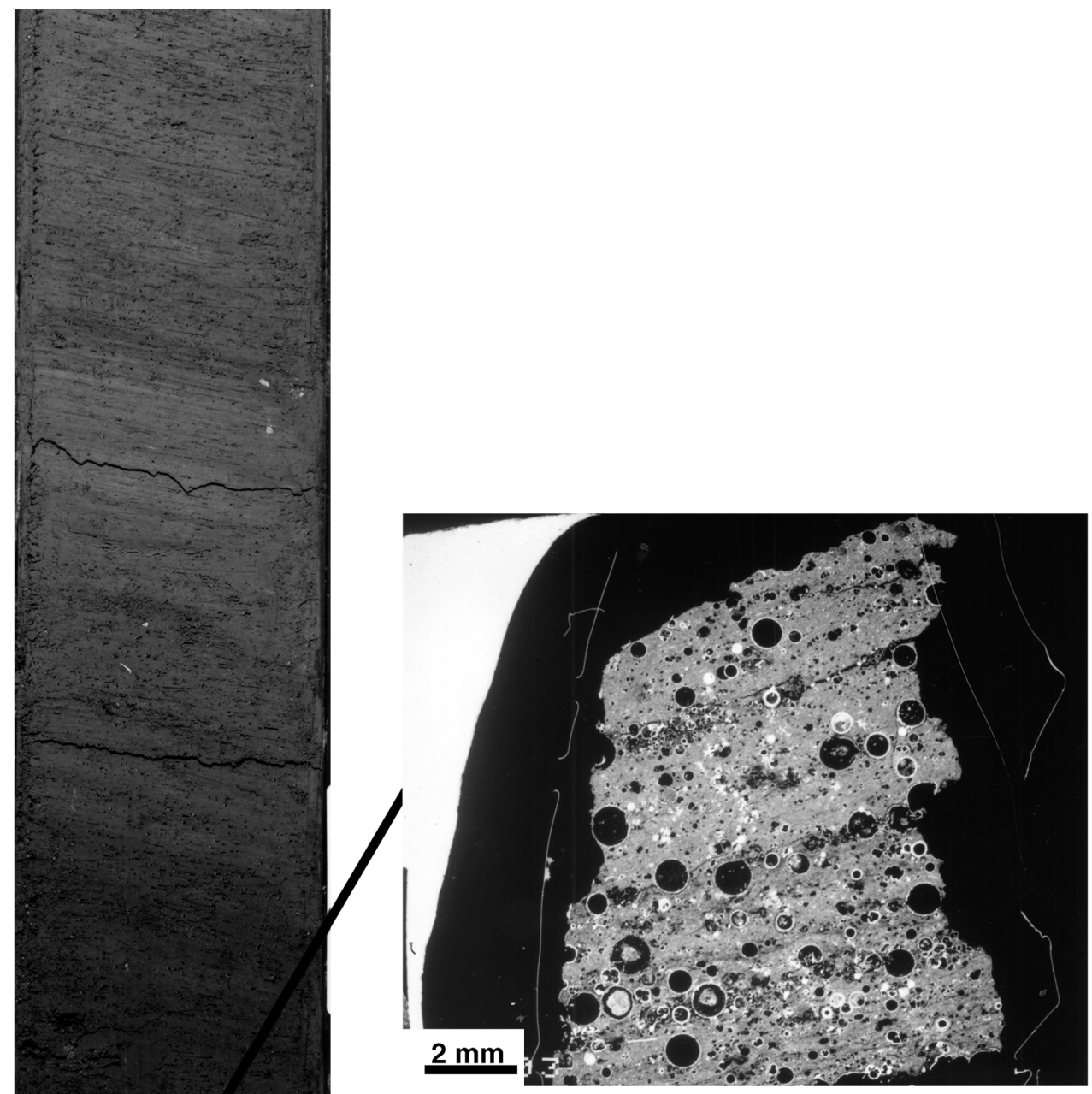

2

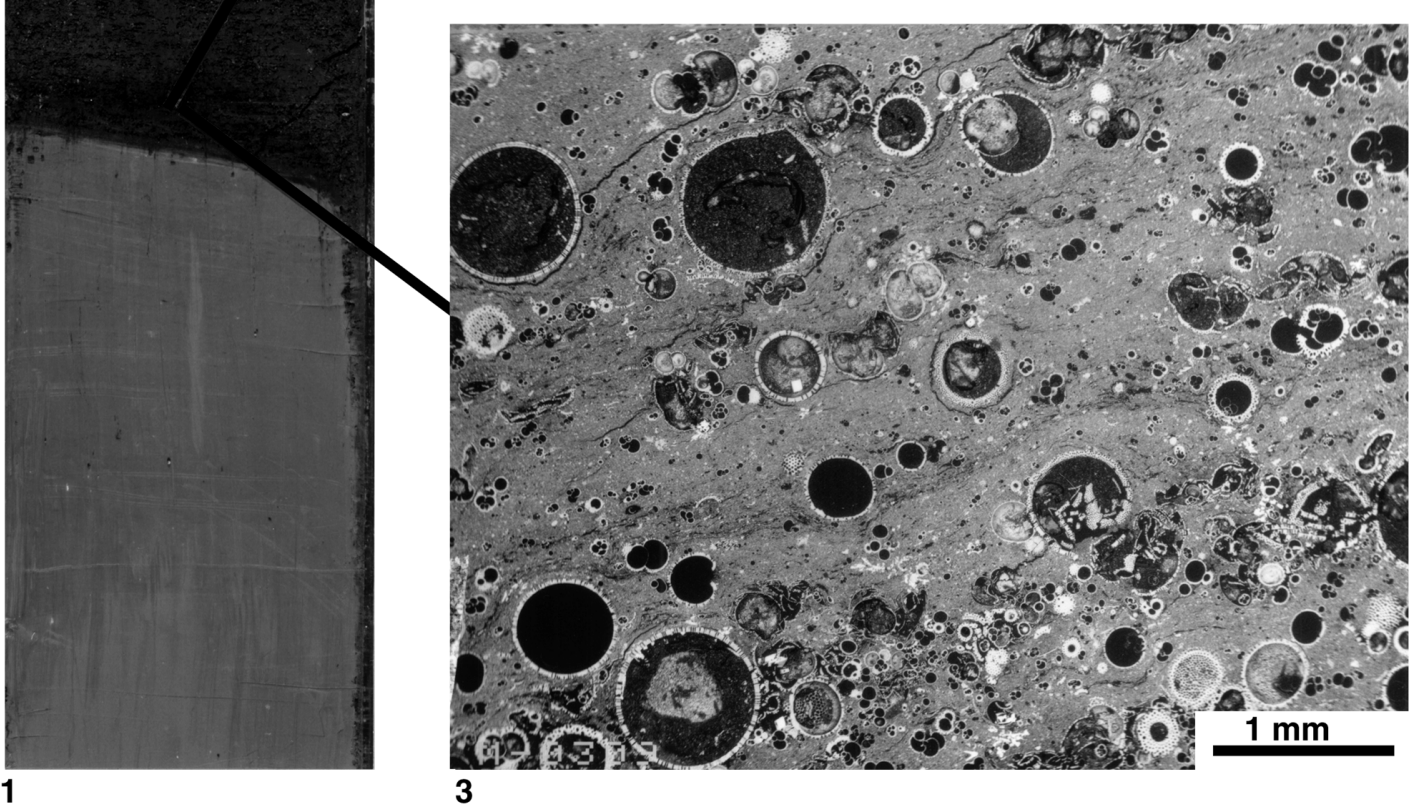

Plate 5. 1. Core photo of sapropel located immediately above the Pliocene/Miocene unconformity at Site 969 (interval 160-969B-11H-6, 98-137 cm). 2. ECP BSEI of foraminifer-rich laminae within the basal Pliocene sapropel (Sample 160-969B-11H-6, 121-125 cm). 3. A higher magnification BSEI of the laminae structure (Sample 160-969B-11H-6, 121-125 cm). 